\title{
Stand structure and species diversity regulate biomass carbon stock under major Central Himalayan forest types of India
}

\author{
Siddhartha Kaushal[D and Ratul Baishya* (D)
}

\begin{abstract}
Background: Data on the impact of species diversity on biomass in the Central Himalayas, along with stand structural attributes is sparse and inconsistent. Moreover, few studies in the region have related population structure and the influence of large trees on biomass. Such data is crucial for maintaining Himalayan biodiversity and carbon stock. Therefore, we investigated these relationships in major Central Himalayan forest types using nondestructive methodologies to determine key factors and underlying mechanisms.

Results: Tropical Shorea robusta dominant forest has the highest total biomass density $\left(1280.79 \mathrm{Mg} \mathrm{ha}{ }^{-1}\right.$ ) and total carbon density (577.77 Mg C ha ${ }^{-1}$ ) along with the highest total species richness (21 species). The stem density ranged between 153 and 457 trees ha ${ }^{-1}$ with large trees (> $70 \mathrm{~cm}$ diameter) contributing 0-22\%. Conifer dominant forest types had higher median diameter and Cedrus deodara forest had the highest growing stock $\left(718.87 \mathrm{~m}^{3}\right.$ $\left.\mathrm{ha}^{-1}\right)$; furthermore, C. deodara contributed maximally toward total carbon density (14.6\%) among all the 53 species combined. Quercus semecarpifolia-Rhododendron arboreum association forest had the highest total basal area (94.75 $\left.\mathrm{m}^{2} \mathrm{ha}^{-1}\right)$. We found large trees to contribute up to $65 \%$ of the growing stock. Nine percent of the species contributed more than $50 \%$ of the carbon stock. Species dominance regulated the growing stock significantly $\left(R^{2}=\right.$ $0.707, p<0.001)$. Temperate forest types had heterogeneous biomass distribution within the forest stands. We found total basal area, large tree density, maximum diameter, species richness, and species diversity as the predominant variables with a significant positive influence on biomass carbon stock. Both structural attributes and diversity influenced the ordination of study sites under PCA analysis. Elevation showed no significant correlation with either biomass or species diversity components.

Conclusions: The results suggest biomass hyperdominance with both selection effects and niche complementarity to play a complex mechanism in enhancing Central Himalayan biomass carbon stock. Major climax forests are in an alarming state regarding future carbon security. Large trees and selective species act as key regulators of biomass stocks; however, species diversity also has a positive influence and should also reflect under management implications.
\end{abstract}

Keywords: Biomass hyperdominance, Elevational gradient, Growing stock, Large trees, Carbon allocation, Forest management

\footnotetext{
*Correspondence: rbaishya@botany.du.ac.in

Ecology \& Ecosystem Research Laboratory, Department of Botany, University of Delhi, Delhi 110007, India
}

\section{Springer Open}

(c) The Author(s). 2021 Open Access This article is licensed under a Creative Commons Attribution 4.0 International License, which permits use, sharing, adaptation, distribution and reproduction in any medium or format, as long as you give appropriate credit to the original author(s) and the source, provide a link to the Creative Commons licence, and indicate if changes were made. The images or other third party material in this article are included in the article's Creative Commons licence, unless indicated otherwise in a credit line to the material. If material is not included in the article's Creative Commons licence and your intended use is not permitted by statutory regulation or exceeds the permitted use, you will need to obtain permission directly from the copyright holder. To view a copy of this licence, visit http://creativecommons.org/licenses/by/4.0/. 


\section{Background}

For adequate ecosystem functioning and management, biomass as well as species diversity together play a critical role and they also address the two most predominant challenges viz. climate change and biodiversity loss. Experimental models and long-term studies under grassland ecosystems have established a positive relationship between species diversity and productivity (Tilman et al. 1997; Tilman et al. 2001). These studies regarded niche complementarity as the underlying principle behind the effects of diversity on productivity with a rationale that resource use and availability is greater under diverse species. However, the effects become more prominent in the long term. In short-term studies, the single species dominant systems appear the most productive (Cardinale et al. 2007). Several studies (Szwagrzyk and Gazda 2007; Day et al. 2014; Mensah et al. 2016; Zhang et al. 2017; Li et al. 2018) under forest ecosystem implicate a positive relationship between tree species diversity and biomass; however, most of them reported weak positive correlation. Furthermore, the tree strata diversity affects the diversity and biomass relation of the understory vegetation (shrubs and herbs). The trend, however, is not ubiquitous. Jacob et al. (2010) reported higher biomass under monocultures than under diverse oldgrowth forest counterparts. While, mature to old-growth primary forests are indispensable for their carbon and biodiversity repository, and it is primarily the presence of large diameter trees that hold major carbon stock in these forests (Gibson et al. 2011). From a global perspective, it is evident that irrespective of their density, the large diameter trees (diameter $>60 \mathrm{~cm}$ ) contribute significantly to biomass and their loss could yield a reduction in structural heterogeneity and the carbon capture potential of forests (Lutz et al. 2018). These mature forests, therefore are more resilient and provide long-term carbon pool reservoirs (Day et al. 2014). Thus, apart from diversity, the forest structure is also critical in deciphering management implications. Estimation of biomass carbon has other imperatives as well. Consumption of fossil fuels leads to greenhouse gas emissions which have increased substantially (Chu 2009). Around $80 \%$ of the total energy consumption in 2018-2019 was from coal, lignite, and crude oil as a major fuel source in India (Energy Statistics 2020). Consequently, the global atmospheric annual $\mathrm{CO}_{2}$ concentration has increased from $338.8 \mathrm{ppm}$ in 1980 to $409.8 \mathrm{ppm}$ in 2019, gaining 71 ppm in only 39 years (Dlugokencky and Tans 2020). Loading of this labile $\mathrm{CO}_{2}$ into the atmospheric carbon (C) pool needs to be managed. One route to achieve this is through mitigation options which involve reducing the emissions and sequestering the labile emissions present into long-term pools (Lal 2008). A practical climate stabilization measure among other sequestration alternatives is terrestrial biotic carbon sequestration. Forest ecosystems are the largest of all terrestrial ecosystems, globally covering 4.06 billion hectares (30.8\%) of area and India contributes $2 \%$ to this global forest area (FAO and UNEP 2020). Forests have a huge repository of $\mathrm{C}$, storing $360 \mathrm{Pg} \mathrm{C}\left(1 \mathrm{Pg}=10^{15} \mathrm{~g}\right)$ in live and dead biomass components along with $398 \mathrm{Pg} \mathrm{C}$ stored in forest soils globally. Along with this, the forest ecosystems sequester around $1.7 \pm 0.5 \mathrm{Pg} \mathrm{C}$ year $^{-1}$. However, destructive anthropogenic activities like deforestation make forests a net source, e.g., deforestation of tropical forests alone release $0.3 \mathrm{Pg} \mathrm{C}_{\mathrm{Cear}}{ }^{-1}$; therefore, the forest ecosystems are not only viable sequestration option but they need efficient management to preserve their $C$ stock (Tans et al. 1990; Lal 2008; Lorenz and Lal 2010). India's forest cover amount to 71.2 million hectares which constitute $21.67 \%$ of the total geographic area (GA) of the country (FSI 2019). Situated in the foothills of the Himalayan mountain ranges lie the Indian state of Uttarakhand; it constitutes the central portion of the Indian Himalayan Region (IHR) (Kafaltia and Kafaltia 2019). Uttarakhand has the second-highest forest growing stock (406.8 million cubic meters) and the fourth-highest forest carbon stock per hectare in aboveground biomass (62.77 $\mathrm{Mg} \mathrm{ha}^{-1}$ ) in India (FSI 2019). In the Central Himalayan grasslands, the species diversity and productivity relationships are well established (Bhattarai et al. 2004; Singh et al. 2005). The information on tree species, however, is inconsistent. Previous studies in the region determined associations between species diversity and biomass; however, elevation attributed the predominant focus, and the impact of diversity or stand structural attributes alone were not elucidated (Singh et al. 1994; Sharma et al. 2010; Gairola et al. 2011). Moreover, the reports revealed contrasting associations between diversity and biomass in Central Himalayas. Gairola et al. (2011) reported no significant correlation between total tree carbon density (TCD) and diversity in twelve major temperate Himalayan forest types, while Sharma et al. (2010) showed a significant negative correlation between TCD and species diversity in their study involving twenty major Garhwal Himalayan forest types. With limited studies under the topic, this creates a need for understanding this relation in Central Himalayas, since apart from carbon management, the conservation of biodiversity is also crucial for optimum ecosystem functioning. Therefore, the present study was undertaken with two broad objectives: (i) determination of growing stock, biomass, and carbon stock of major forest types in Central Himalaya along with their comparison with similar forest types to access their status, and (ii) understanding the effects of stand structural attributes and species diversity on biomass and carbon stocks. 


\section{Materials and methods}

\section{Study area description}

The Garhwal Himalayas of Uttarakhand state in India (Fig. 1) which lies in the central portion of the Indian Himalayan Region covering an area of around 32,449 $\mathrm{km}^{2}$ represented our study area. Situated in the foothills of the Himalayas, it gives rise to the two prominent river systems the Ganges and the Yamuna-Tons basin (Nandy et al. 2006). The study sites are situated in two districts viz. Dehradun and Rudraprayag lying between $30^{\circ} 00^{\prime}$ $\mathrm{N}-30^{\circ} 46^{\prime} \mathrm{N}$ latitude and $77^{\circ} 48^{\prime} \mathrm{E}-79^{\circ} 12^{\prime} \mathrm{E}$ longitude covering an elevational range of around $3000 \mathrm{~m}$. To select areas that represent major forest types of Uttarakhand, we selected the forest types having the maximum forest cover in the state as per FSI (2019) report. The forest types thus selected represents $63.4 \%$ of Uttarakhand's forest cover (FSI 2019). We conducted a preliminary reconnaissance study in 2017 to select the study areas that comprise of these forest types. The selected areas represent large stands of a particular forest type, constitute naturally regenerating forests without plantations, and have a protected legal status to minimize anthropogenic influence. Based on these criteria along with the ease of access and availability of field research permission, we selected eight forest types as per Champion and Seth (1968) forest type classification (detailed in Table 1 and Supplementary Table S1). Physiographically, the region rises from the Bhabar-Siwalik zone of the outer Himalaya to the Himadri of the inner Himalayas (Rajwar 1993). F1 (RNP) and F2 (ASA) had generally flat topography with a $<10 \%$ slope. All the other sites (F3-F8) had undulating hilly terrain with highly variable slope angles in a range of $20^{\circ}$ to $35^{\circ}$ and with low $(<30 \%)$ to medium $(30-80 \%)$ rockiness. The region has a seasonal climate with three major seasons, i.e., winter season (November to February), summer season (April to June), and rainy (July to September). A small period of spring (March) and autumn (October) are also present between the seasons (Singh and Singh 1987).

The overall climate follows the monsoon pattern of rainfall having most of the annual rainfall from mid-June to mid-September. Therefore, the summers represent the warm dry months and the rainy season represents the warm and wet months. The maximum temperature in 2019 ranged between 24 and $46{ }^{\circ} \mathrm{C}$ and minimum between 3 and $-30{ }^{\circ} \mathrm{C}$ (AccuWeather $\odot$, Inc. 2020).

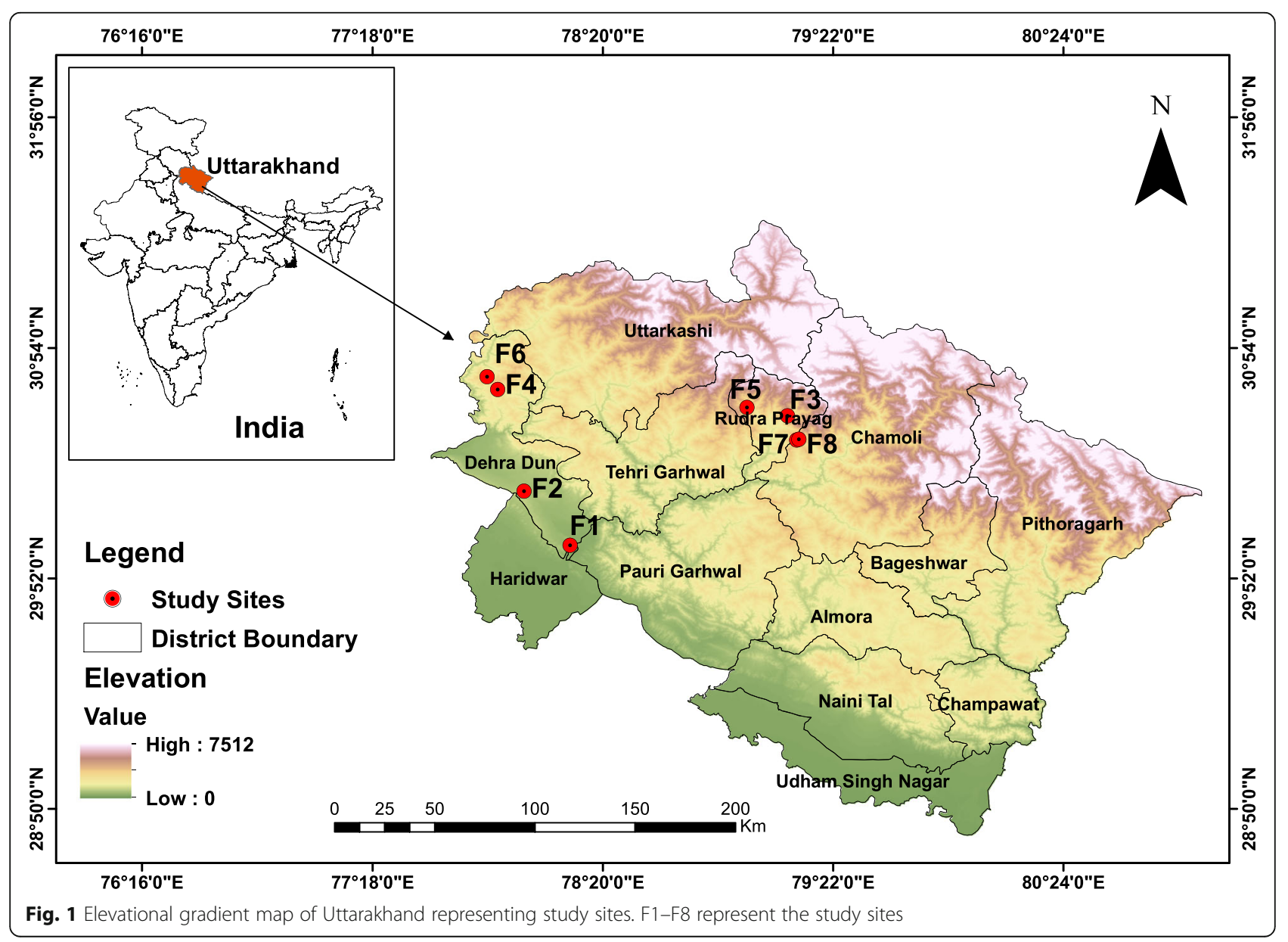


Table 1 Study areas with their general properties

\begin{tabular}{|c|c|c|c|c|c|}
\hline $\begin{array}{l}\text { Site } \\
\text { code }\end{array}$ & Location (District) & $\begin{array}{l}\text { Avg. elevation } \\
\text { (m) }\end{array}$ & Forest type group* & $\begin{array}{l}\text { Forest type } \\
\text { (Class) }^{\mathrm{a}}\end{array}$ & Legal status \\
\hline F1 (RNP) & $\begin{array}{l}\text { Motichur Range } \\
\text { (Dehradun) }\end{array}$ & 330 & $\begin{array}{l}\text { Tropical Moist Deciduous } \\
\text { Forests }\end{array}$ & $\begin{array}{l}\text { Moist Siwalik } \\
\text { Sal Forest }\left(3 C / C_{2} a\right)\end{array}$ & Rajaji National Park (Core Zone) \\
\hline F2 (ASA) & Asarori Range (Dehradun) & 710 & & $\begin{array}{l}\text { Bhabar-Dun } \\
\text { Sal Forest (3C/ } \\
\left.\mathrm{C}_{2} \mathrm{~b}(\mathrm{i})\right)\end{array}$ & Reserve Forest \\
\hline $\begin{array}{l}\mathrm{F} 3 \\
(\mathrm{GON})\end{array}$ & Gondar (Rudraprayag) & 1663 & Sub-tropical Pine Forests & $\begin{array}{l}\text { Upper or Himalayan } \\
\text { Chir Pine Forest } \\
\left(9 / C_{1} b\right)\end{array}$ & $\begin{array}{l}\text { Kedarnath Wildlife Sanctuary (Core } \\
\text { Zone) }\end{array}$ \\
\hline $\mathrm{F} 4(\mathrm{CHK})$ & Chakrata (Dehradun) & 2140 & $\begin{array}{l}\text { Himalayan Moist Temperate } \\
\text { Forests }\end{array}$ & $\begin{array}{l}\text { Ban Oak Forest } \\
\left(12 / C_{1} a\right)\end{array}$ & Reserve Forest \\
\hline F5 (TYN) & $\begin{array}{l}\text { Triyuginarayan } \\
\text { (Rudraprayag) }\end{array}$ & 2158 & & $\begin{array}{l}\text { Moist temperate } \\
\text { deciduous forest } \\
\left(12 / C_{1} e\right)\end{array}$ & $\begin{array}{l}\text { Kedarnath Wildlife Sanctuary (Core } \\
\text { Zone) }\end{array}$ \\
\hline F6 (KAN) & Kanasar (Dehradun) & 2285 & & $\begin{array}{l}\text { Moist Deodar } \\
\text { Forest }\left(12 / C_{1} C\right)\end{array}$ & Reserve Forest \\
\hline F7 (CHP) & Chopta (Rudraprayag) & 2980 & & $\begin{array}{l}\text { Kharsu Oak } \\
\text { Forest }\left(12 / \mathrm{C}_{2} \mathrm{a}\right)\end{array}$ & $\begin{array}{l}\text { Kedarnath Wildlife Sanctuary (Core } \\
\text { Zone) }\end{array}$ \\
\hline F8 (TUN) & Tungnath (Rudraprayag) & 3300 & Sub-alpine Forests & $\begin{array}{l}\text { West Himalayan } \\
\text { Fir Forest }\left(14 / C_{1} b\right)\end{array}$ & $\begin{array}{l}\text { Kedarnath Wildlife Sanctuary (Core } \\
\text { Zone) }\end{array}$ \\
\hline
\end{tabular}

al: Shorea robusta Gaertn.; Chir Pine: Pinus roxburghii Sarg.; Ban Oak: Quercus oblongata D. Don (Syn. Q. leucotrichophora A. Camus); Deodar: Cedrus deodara (Roxb. Ex Lamb.) G. Don; Kharsu: Quercus semecarpifolia Sm.; Fir: Abies species

a Forest type groups and classes are based upon Champion and Seth (1968) forest type classification

Snowfall in higher elevations begins as early as October with heavy snowfall during January and February in temperate and sub-alpine elevations. In the sub-alpine elevation, F8 (TUN) the snowfall can continue up to April (Rai et al. 2020).

Furthermore, the microclimate within an area also varies due to slope aspects, topographic relief, windward, and leeward sides, and even position on the ridge (Kafaltia and Kafaltia 2019). Geologically, the study sites lie in three major tectonic belts viz. (a) the Sub-Himalayan (SH) belt in the lower elevations comprising of clays, sandstones, and conglomerates; (b) Lesser Himalayan (LH) belt which predominantly comprises of sedimentary rocks, limestones, grits, shales, and schists; and (c) The Higher Himalayan Crystalline (HHC) belt mainly comprising of gneisses and granite (Rajwar 1993; Mukherjee et al. 2019).

\section{Study design and vegetation sampling}

Based on FSI field inventory manual, we classified the general properties of the area like legal status, topography, and rockiness (FSI 2002). The geographic coordinates and elevation were estimated using a handheld GPS logger (Garmin. GPS $72^{\mathrm{mm}}$ ) and the slope angle for the sites was determined using the topographic relief map from Google Maps (https://www.google.com/maps). For forest inventory, we randomly laid square quadrats of dimensions $31.6 \mathrm{~m} \times 31.6 \mathrm{~m}(\sim 0.1 \mathrm{ha})$ in each forest type. The minimum distance between the quadrats was not less than $300 \mathrm{~m}$ while in some forest types it was as large as $5000 \mathrm{~m}$. The plot size is based on FSI field inventory manual (FSI 2002), and is adopted by other investigators in Himalayan forest types (Thokchom and Yadava 2017; Banik et al. 2018; Sharma et al. 2018). In each forest type F1-F6, we laid ten quadrats $(10 \times 0.1=$ 1 ha); however, for upper temperate and sub-alpine elevations F7 and F8 due to harsh terrain and climatic conditions, we placed only five quadrats each $(5 \times 0.1=$ $0.5 \mathrm{ha})$. Overall, 70 quadrats $(7 \mathrm{ha})$ were laid to cover the forest types in this study. Within each quadrat, we identified all the tree species, i.e., species that classify as trees in their growth form by recognized floras, and have a diameter $\geq 10 \mathrm{~cm}$ at breast height $(137 \mathrm{~cm}$ from the ground). The circumference over bark was measured at breast height $(\mathrm{CBH})$ using a measuring tape as per standard rules (Singh et al. 1994; UNFCCC 2015). For taxonomic identification, we consulted local floras viz. Flora of the district Garhwal (Gaur 1999), Flora of Jaunsar Bawar (Agarwal 2017), Flora of Rajaji National Park (Singh and Prakash 2002), Plants of Kedarnath Wildlife Sanctuary, Western Himalaya: a field guide (Rai et al. 2017) as well as the taxonomic knowledge from the local community.

\section{Stand structure and species diversity}

The stand structure or the population structure was analyzed using density-diameter curves which were plotted along with the growing stock volume for a comparative 
visualization. The distribution and skewness of the DBH distribution are represented using a box-whisker plot indicating the overall girth distribution along with the distribution pattern of large trees $(\mathrm{DBH}>70 \mathrm{~cm})$. Various studies use different criteria to delineate large trees ranging from $>60 \mathrm{~cm} \mathrm{DBH}$ to $>100 \mathrm{~cm}$, and even associated biomass values (Lutz et al. 2013; Sist et al. 2014). In the absence of any unified classification system for the Himalayan region, we regard trees with $\mathrm{DBH}>70 \mathrm{~cm}$ as large trees since this parameter is used by various investigators (Brown and Lugo 1992; Slik et al. 2013; Bradford and Murphy 2019) thus facilitating easier comparisons. To determine the species dominance, we calculated the Importance Value Index (IVI) for each species. Summation of relative density, relative frequency, and relative basal area of the species constituted the IVI (Misra 1968). General species richness was attributed to the total species richness (TSR): number of distinct species in each forest type. To incorporate sampling adequacy, we used Margalef's richness (MR) index to characterize species richness. Margalef's richness index, MR $=(T S R-$ 1)/ $\ln$ (total number of individuals) (Margalef 1958). Species diversity was computed using the Shannon-Wiener index $\left(H^{\prime}\right)$ which is the most widely used diversity index. $H^{\prime}=-\Sigma p_{i} \ln p_{i}$, here $p_{i}=n i / n$ wherein $n_{i}$ is the IVI of $i$ th species and $n$ is the total IVI of all the species (Shannon and Weaver 1949; Magurran 2004).

\section{Growing stock, biomass, and carbon stock estimation}

Since the climatic, edaphic, and topographic factors along with inherent anthropogenic influence modulate the biomass of a region, therefore, the use of general biomass allometric equations might be inaccurate for region-specific studies (Brown and Iverson 1992; Zianis 2008). Moreover, since destructive biomass sampling is prohibited in protected forest areas, and species-specific or general allometric equations for biomass estimation are not available for most of the species in the Indian Himalayan region, therefore we used a volume-based method. Other investigators (Brown et al. 1999; Chhabra et al. 2002; Dimri et al. 2017a) also used a similar approach. For each individual, wood volume $\left(\mathrm{m}^{3}\right)$ was therefore determined using species and region-specific volume equations (detailed in Table 2) as per the Forest Survey of India publications (FSI 1996; FSI 2011). For species where equations were not available, we used either genus-specific or general equations for the region (Table 2). The growing stock volume density (GSVD, $\mathrm{m}^{3}$ $\mathrm{ha}^{-1}$ ) for each forest type and their constituent species was determined through the summation of volume for each tree individual. Since for forest types, F7 and F8 only 0.5 ha area were sampled, the summation of growing stock volume (species wise) was extrapolated to 1 ha. To convert GSVD into aboveground biomass density
(AGBD, $\mathrm{Mg} \mathrm{ha}^{-1}$ ), we multiplied the GSVD with appropriate biomass expansion factor $\left(\mathrm{BEF}, \mathrm{Mg} \mathrm{m}^{-3}\right.$ ) which converts wood volume into biomass and accounts for non-commercial tree components like branches, twigs, bark, foliage, and reproductive parts thus, providing total tree AGBD (Schroeder et al. 1997). Table 3 details the regression equations of BEFs and BEF values (Brown et al. 1999). To determine the belowground biomass density (BGBD, $\mathrm{Mg} \mathrm{ha}^{-1}$ ) which represents the biomass of root components, we used the regression equation (Table 3) given by Cairns et al. (1997) (Brown et al. 1999). The equation determines the BGBD based upon AGBD and latitudinal zone (temperate zone in our case). Summation of AGBD and BGBD yields the total biomass density (TBD, $\mathrm{Mg} \mathrm{ha}^{-1}$ ) for trees. For aboveground carbon density (AGCD, $\mathrm{Mg} \mathrm{C} \mathrm{ha}^{-1}$ ) and total carbon density (TCD, $\mathrm{Mg} \mathrm{C} \mathrm{ha}^{-1}$ ), we multiplied the AGBD and TBD, respectively with species-specific carbon factor. If factors were unavailable for a species, broad factors were used, i.e., $46.19 \%$ for conifers; $45.02 \%$ for dicot, deciduous; $44.91 \%$ for dicot, evergreens; and $45.37 \%$ for exotic species like Eucalyptus (Negi et al. 2003).

\section{Statistical analysis}

To understand the impact of species dominance over growing stock distribution, we ran a linear regression between $\log _{\mathrm{e}}$ IVI and $\log _{\mathrm{e}}$ GSVD (at species level) to quantify the dependence between the variables. For determining the evenness in growing stock distribution within the forest types, we used one-way analysis of variance (ANOVA) to compare means of GSVD at quadrat level within forest types. A two-tailed Pearson's correlation between the topographic (elevation) variable, total stem density, large tree stem density, maximum tree diameter, TBA, GSVD, TBD, TCD, TSR, MR, and $H^{\prime}$ using IBM SPSS software (Ver. 23.0.0.0) determined the degree and direction of the association between the variables. Mean values for the entire forest types were used to run the correlation to avoid error bias due to plot variances because of the smaller plot size $(0.1 \mathrm{ha})$. The dimension reduction was done by principal component analysis (PCA) using Paleontological Statistics software (PAST, Version 4.03) of biomass variable (TBD), species richness variables (TSR and MR), diversity variable $\left(H^{\prime}\right)$, and stand structure variable (large tree stem density). PCA was run using a correlation matrix, and components with cumulative eigenvalue (as \%) $80 \%$ or greater were retained. Furthermore, a scree plot of eigenvalues (as \% variation) is also considered, and components at the elbow point (below the broken stick model) were considered less significant (Zuur et al. 2007). Loading coefficients and PCA biplot were used to interpret the association between the variables and principal axes. 
Table $\mathbf{2}$ List of volume equations for the tree species in the study sites

\section{Tree species}

Abies spectabilis (D. Don) Mirb.

Acer caesium Wall. ex Brandis

Acer sterculiaceum Wall.

Aegle marmelos (L.) Corrêa

Aesculus indica (Wall. ex Cambess.) Hook.

Albizia procera (Roxb.) Benth.

Alnus nepalensis D.Don

Betula alnoides Buch. -Ham. ex D.Don

Cedrus deodara (Roxb. ex D. Don) G.Don

Cupressus torulosa D.Don ex Lamb.

Eucalyptus tereticornis Sm.

Ficus benghalensis $\mathrm{L}$.

Ficus religiosa $\mathrm{L}$.

Holarrhena pubescens Wall. ex G. Don

Juglans regia L.

Lyonia ovalifolia (Wall.) Drude

Mallotus nudiflorus (L.) Kulju \& Welzen

Mallotus philippensis (Lam.) Müll.Arg.

Mitragyna parvifolia (Roxb.) Korth.

Picea smithiana (Wall.) Boiss.

Pinus roxburghii Sarg.

Pinus wallichiana A.B. Jacks.

Quercus floribunda Lindl. ex A. Camus

Quercus glauca Thunb.

Quercus oblongata D. Don

Quercus semecarpifolia Sm.

Rhododendron arboreum Sm.

Senegalia catechu (L.f.) P.J.H. Hurter \& Mabb.

Shorea robusta C.F. Gaertn.

Syzygium cumini (L.) Skeels

Taxus wallichiana Zucc.

Tectona grandis L.f.

Terminalia anogeissiana Gere \& Boatwr.

Terminalia bellirica (Gaertn.) Roxb.

Terminalia elliptica Willd.

$$
\begin{aligned}
& \text { Volume equations } \\
& V=0.22742-1.06194 D+7.21004 D^{2}+3.04194 D^{3} \\
& \sqrt{V}=-0.10851+3.04250 D \\
& V / D^{2}=0.16609 / D^{2}-2.78851 / D+17.22127-11.60248 D \\
& \sqrt{V}=0.220191+3.923711 D-1.117475 \sqrt{D} \\
& V=-0.043832+3.262852 D^{2} \\
& \sqrt{V}=-0.136676+3.60113 D \\
& V=-0.12110+1.58826 D+1.96643 D^{2} \\
& V=-0.00165+8.209795 D^{2} \\
& \log _{e} V=2.101388+2.418695 \log _{e} D \\
& \sqrt{V}=-0.0868+2.8335 D \\
& \sqrt{V}=0.03629+3.95389 D-0.84421 \sqrt{D} \\
& V=0.17994-2.78776 D+14.44961 D^{2} \\
& \sqrt{V}=-0.207229+3.254007 D \\
& V=0.03468-0.56878 D+4.72282 D^{2} \\
& \sqrt{V}=-0.45312-0.41426 D+2.10913 \sqrt{D} \\
& V=0.14749-2.87503 D+19.61977 D^{2}-19.11630 D^{3} \\
& V / D^{2}=0.099768 / D^{2}-1.744274 / D+10.086934 \\
& V / D^{2}=0.26072 / D^{2}-3.29692 / D+14.71246 \\
& V=0.12844-2.23711 D+11.78506 D^{2}-0.56094 D^{3} \\
& V=0.223139-2.35096 D+11.90669 D^{2} \\
& \sqrt{V}=0.47511-4.93282 D-2.450475 \sqrt{D} \\
& V=0.06839-0.95816 D+6.06105 D^{2}+2.66635 D^{3} \\
& V=0.08355-1.28586 D+8.76867 D^{2}+1.1215 D^{3} \\
& V=0.06007-0.21874 \sqrt{D}+3.63428 D^{2} \\
& V=0.02384-0.72161 D+7.46888 D^{2} \\
& V=0.03085-0.77794 D+8.42051 D^{2}+5.91067 D^{3} \\
& V / D^{2}=0.09809 / D^{2}-1.94468 / D+13.36728-6.33263 D \\
& V=0.487126+3.698924 D-1.856459 \sqrt{D} \\
& V=0.08847-1.46936 D+11.98979 D^{2}+1.97056 D^{3} \\
& \sqrt{V}=0.46976+5.99849 D-2.60729 \sqrt{D} \\
& \sqrt{V}=-0.0233308+2.803750 D
\end{aligned}
$$

Adina cordifolia (Roxb.) Brandis; Ailanthus excelsa Roxb.; Cassia fistula L.; Grevillea robusta A. Cunn. ex R.Br.; Holoptelea integrifolia (Roxb.) Planch.; Naringi crenulata (Roxb.) Nicolson; Schleichera oleosa (Lour.) Oken: For these species general volume equation for Lansdowne/Yamuna/Tehri/Garhwal division was used.

\section{$V=0.03843-0.36982 D+2.62185 D^{2}+7.68659 D^{3}$}

Buxus wallichiana Baill.; Carpinus viminea Lindl. ex Wall.; Cornus capitata Wall.; Daphniphyllum himalense (Benth.) Müll.Arg.; Euonymus tingens Wall.; llex dipyreana Wall.; Machilus odoratissima Nees; Neolitsea pallens (D.Don) Momiy. \& H. Hara; Prunus cornuta (Wall. ex Royle) Steud.; Pyrus pashia Buch.Ham. ex D. Don; Sorbus foliolosa (Wall.) Spach.: For these species general volume equation for Alaknanda catchment/Chamoli/Pauri Garhwal was used. $\sqrt{V}=0.60124+5.32265 D-2.92195 \sqrt{D}$

$V$ volume $\left(\mathrm{m}^{3}\right)$ under bark, $D$ diameter at breast height $(1.37 \mathrm{~m})$ over bark in meters Reference: Aegle marmelos (FSI 2011), rest all the equations are from FSI (1996) 
Table 3 Biomass expansion factor (BEF) values/regression equations and belowground biomass density (BGBD) regression equation

\begin{tabular}{|c|c|c|}
\hline Forest types & GSVD value $\left(\mathrm{m}^{3} \mathrm{ha}^{-1}\right)$ & BEF equation/value $\left(\mathrm{Mg} \mathrm{m}^{-3}\right)$ \\
\hline \multirow[t]{2}{*}{ Hardwoods } & GSVD > 200 & 1.0 \\
\hline & GSVD $<200$ & $\mathrm{BEF}=\exp \{1.91-0.34 \times \ln (\mathrm{GSVD})$ \\
\hline \multirow[t]{2}{*}{ Spruce-fir } & GSVD $>160$ & 1.0 \\
\hline & GSVD $<160$ & $\mathrm{BEF}=\exp \{1.77-0.34 \times \ln (\mathrm{GSVD})\}$ \\
\hline \multirow[t]{3}{*}{ Pine } & GSVD $<10$ & 1.68 \\
\hline & GSVD $=10-100$ & 0.95 \\
\hline & GSVD $>100$ & 0.81 \\
\hline
\end{tabular}

BGBD $\left(\mathrm{Mg} \mathrm{ha}^{-1}\right)=\exp \left[(-1.0587)+\left(0.8836 \times \operatorname{Ln}\left(A G B D, \mathrm{Mg} \mathrm{ha}^{-1}\right)\right)+(0.284)\right]$

exp exponent, $L n$ natural logarithm

\section{Results}

\section{Stand structure and species diversity}

Forest types F2, F6, and F8 are pure stands of S. robusta, C. deodara, and Abies spectabilis respectively with more than $80 \%$ of the total tree density, while the remaining forest types are of mixed stand type (Supplementary Table S2). The stem density ranged from 153 to 457 trees ha ${ }^{-1}$ (Table 4). The maximum stem density was recorded in $30-40 \mathrm{~cm}$ DBH class (21.6\%) in F1, 20-30 cm $\mathrm{DBH}$ class (32.6\%) in F2, 10-20 cm DBH class (23.5\%) in F3, 30-40 cm DBH class (30\%) in F4, 10-20 cm and 20-30 cm (30\% each) DBH class in F5, 60-70 cm DBH class $(17.5 \%)$ in $\mathrm{F} 6,10-20 \mathrm{~cm} \mathrm{DBH}$ class (19.6\%) in F7, and $30-40 \mathrm{~cm} \mathrm{DBH}$ class (31\%) in F8 (Fig. 2). Contribution of large trees toward stem density was $10.8 \%, 0 \%$, $20.9 \%, 3.6 \%, 8.9 \%, 22.3 \%, 19 \%$, and $18.4 \%$ in F1 to $\mathrm{F} 8$ respectively (Fig. 3). On average, large trees were more concentrated in temperate and sub-alpine forest types. The TBA ranged between 94.75 (F7) and 37.40 (F3) $\mathrm{m}^{2}$ $\mathrm{ha}^{-1}$ (Table 4). Conifer dominant forest types F6 (51.9 $\mathrm{cm})$, F3 $(49.7 \mathrm{~cm})$, and F8 $(44.9 \mathrm{~cm})$ had the highest median DBH (Fig. 3). F2, F4, and F5 had the least spread indicating trees with even $\mathrm{DBH}$ distribution (Fig. 2 and Fig. 3). F3 showed the greatest spread indicated by its interquartile (IQ) range along with a higher

Table 4 Tree parameters, growing stock, biomass, and carbon stock for forest types studied

\begin{tabular}{lllllllll}
\hline Site & SD & TBA & GSVD & AGBD & AGCD & BGBD & TBD & TCD \\
\hline F1 & 232 & 48.76 & 581.70 & 1001.76 & 451.92 & 279.03 & 1280.79 & 577.77 \\
F2 & 457 & 38.60 & 425.00 & 457.06 & 208.47 & 109.11 & 566.17 & 258.22 \\
F3 & 153 & 37.40 & 409.15 & 471.82 & 215.66 & 124.36 & 596.18 & 272.52 \\
F4 & 360 & 50.43 & 399.52 & 499.37 & 229.09 & 134.83 & 634.20 & 290.92 \\
F5 & 351 & 50.92 & 447.70 & 757.39 & 342.06 & 211.17 & 968.56 & 437.45 \\
F6 & 275 & 67.24 & 718.87 & 758.83 & 350.20 & 176.57 & 935.40 & 431.65 \\
F7 & 368 & 94.75 & 668.56 & 674.63 & 311.25 & 158.27 & 832.90 & 384.27 \\
F8 & 174 & 40.53 & 402.36 & 485.90 & 223.80 & 122.02 & 607.92 & 279.97 \\
\hline
\end{tabular}

SD stem density (trees ha $\left.{ }^{-1}\right) ;$ TBA total basal area $\left(\mathrm{m}^{2} \mathrm{ha}^{-1}\right)$; GSVD $\left(\mathrm{m}^{3} \mathrm{ha}^{-1}\right)$; AGBD (Mg ha $\left.{ }^{-1}\right)$; AGCD: (Mg Cha $\left.{ }^{-1}\right)$; BGBD: $\left(\mathrm{Mg} \mathrm{ha}^{-1}\right)$; TBD: $\left(\mathrm{Mg} \mathrm{ha}^{-1}\right)$; TCD: $(\mathrm{Mg} \mathrm{C} \mathrm{ha-1)}$ concentration of trees in the lower DBH $\left(25^{\text {th }}-50^{\text {th }}\right.$ percentile) quartile (Fig. 3). Large trees were predominantly outliers to extreme outliers in all the forest types indicating their rarity (Fig. 2 and Fig. 3). Overall, 53 tree species were present in all the forest types. F1 had the greatest number of tree species (21) followed by F5 (18) (Supplementary Table S2). Margalef's richness index ranged between 0.58 (F7) and 3.67 (F1). Shannon's diversity index varied from 0.77 (F2) to 2.63 (F1).

\section{Growing stock, biomass, and carbon stock}

GSVD ranged between $399.52 \mathrm{~m}^{3} \mathrm{ha}^{-1}$ (F4) and 718.87 $\mathrm{m}^{3} \mathrm{ha}^{-1}$ (F6) (Table 4). F1 had the highest AGBD (1001.76 Mg ha-1), AGCD (451.92 Mg C ha ${ }^{-1}$ ), BGBD (279.03 $\left.\mathrm{Mg} \mathrm{ha}^{-1}\right)$, TBD (1280.79 $\mathrm{Mg} \mathrm{ha}^{-1}$ ), and TCD (577.77 $\mathrm{Mg} \mathrm{C} \mathrm{ha}{ }^{-1}$ ) in our study (Table 4). At the species level, $C$. deodara had the maximum percentage contribution of $14.56 \%$ to the TCD, followed by $S$. robusta (12.28\%) and Q. semecarpifolia (9.96\%) (Supplementary Table S3). Gymnosperms contributed $28.54 \%$ to the TCD while the angiosperms contributed the remaining $71.46 \%$.

The maximum GSVD contribution was by $>100 \mathrm{~cm}$ DBH class $(32 \%)$ in $\mathrm{F} 1,40-50 \mathrm{~cm}$ DBH class (35\%) in $\mathrm{F} 2,>100 \mathrm{~cm} \mathrm{DBH}$ class in F3, 50-60 cm DBH class $(22.2 \%)$ in $\mathrm{F} 4,>100 \mathrm{~cm}$ DBH class $(40.7 \%)$ in F5, 60-70 cm DBH class (23.3\%) in F6, > $100 \mathrm{~cm} \mathrm{DBH}$ class (30\%) in F7, and $60-70 \mathrm{~cm} \mathrm{DBH}$ class (14.9\%) in F8 (Fig. 2). Large trees contributed $49.1 \%, 0 \%, 58.2 \%, 15.5 \%, 64.5 \%$, $50.1 \%, 65.1 \%$, and $46.2 \%$ toward GSVD in forest types F1-F8 respectively (Fig. 2). Under Moist Siwalik Sal forest (F1), $S$. robusta contributed the maximum to GSVD (34.22\%) and TCD (21.88\%). In the Bhabar-Dun Sal forest (F2), S. robusta contributed $98.06 \%$ toward GSVD and $90.52 \%$ for TCD. In the sub-tropical Himalayan Chir Pine forest (F3), Pinus roxburghii contributed $51.48 \%$ toward GSVD; however, the maximum contribution to TCD was by Alnus nepalensis (39.47\%). Quercus oblongata had the maximum GSVD (50.34\%) and TCD (43.77\%) in (F4) Ban Oak forest. Aesculus indica contributed predominantly in the moist temperate deciduous 

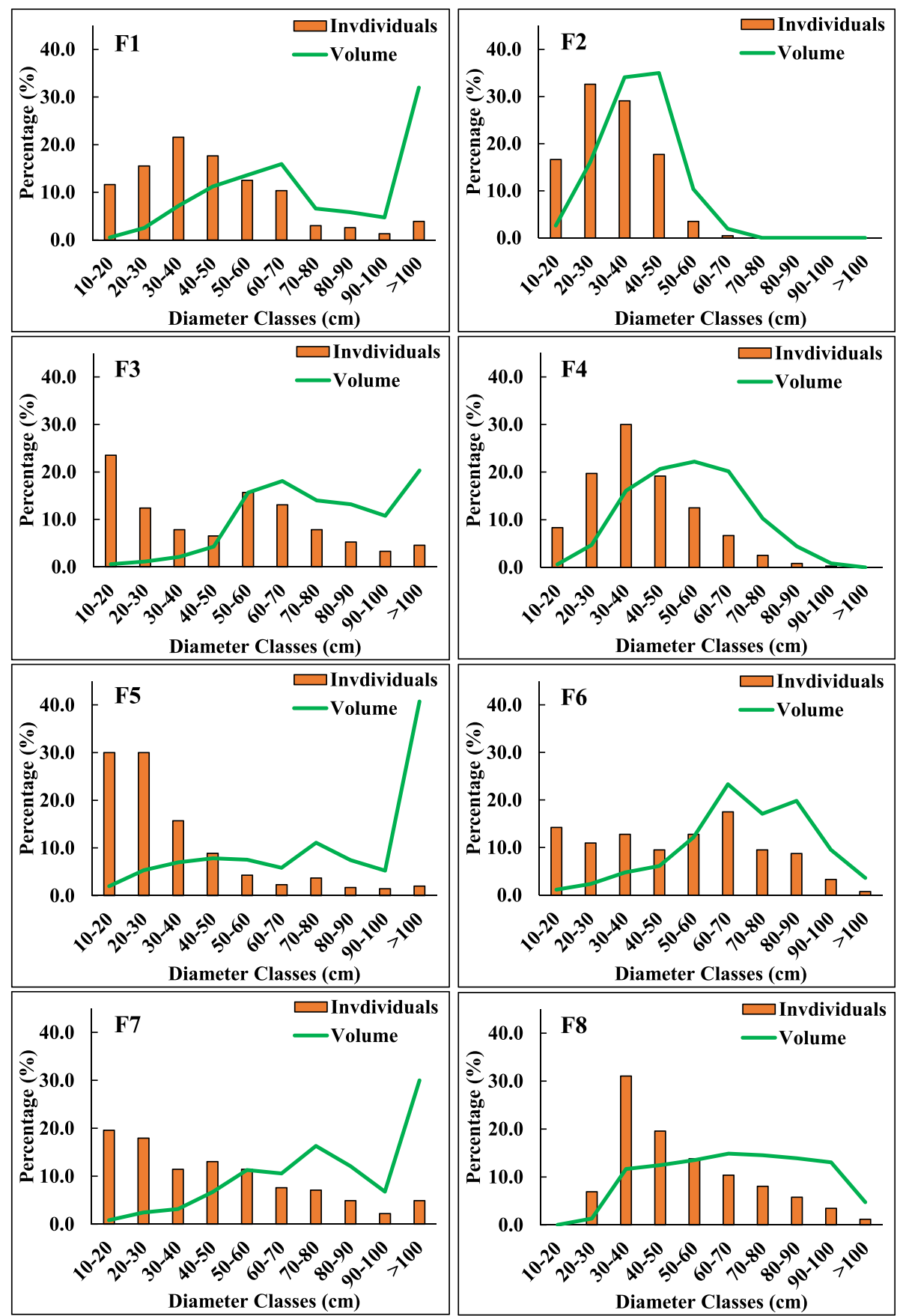

Fig. 2 Graphical distribution of tree density and growing stock volume corresponding to their diameter classes. F1-F8 represents the study sites

forest (F5) toward GSVD (42.96\%) and TCD (27.87\%). C. deodara had the highest GSVD (85.20\%) and TCD (79.85\%) in moist Deodar forest (F6). Q. semecarpifolia contributed maximum toward GSVD (66.78\%) and TCD (65.75\%) in Kharsu oak forest (F7). A. spectabilis was the dominant contributor to GSVD (84.61\%) and TCD (69.30\%) in the sub-alpine Himalayan Fir forest (F8) (Supplementary Table S2). AGBD contributed an average of $79.6 \pm 1.2 \%$ to the TBD while the belowground biomass contributed $20.4 \pm 1.2 \%$ in this study. Tropical (F1 and F2) and sub-alpine forest (F8) types showed homogenous GSVD distribution. However, the subtropical (F3) and temperate (F4-F7) forest types showed a statistically significant difference in growing stock volume between the quadrats under each forest type [F3: $F(9,143)=4.40, p<0.001 ; \mathrm{F} 4: \mathrm{F}(9,349)=3.98, p<$ 0.001; F5: $F(9,341)=2.55, p=0.008$; F6: $F(9,263)=$ 3.26, $p<0.001$, and F7: $F(4,179)=4.33, p=0.002$ ] 


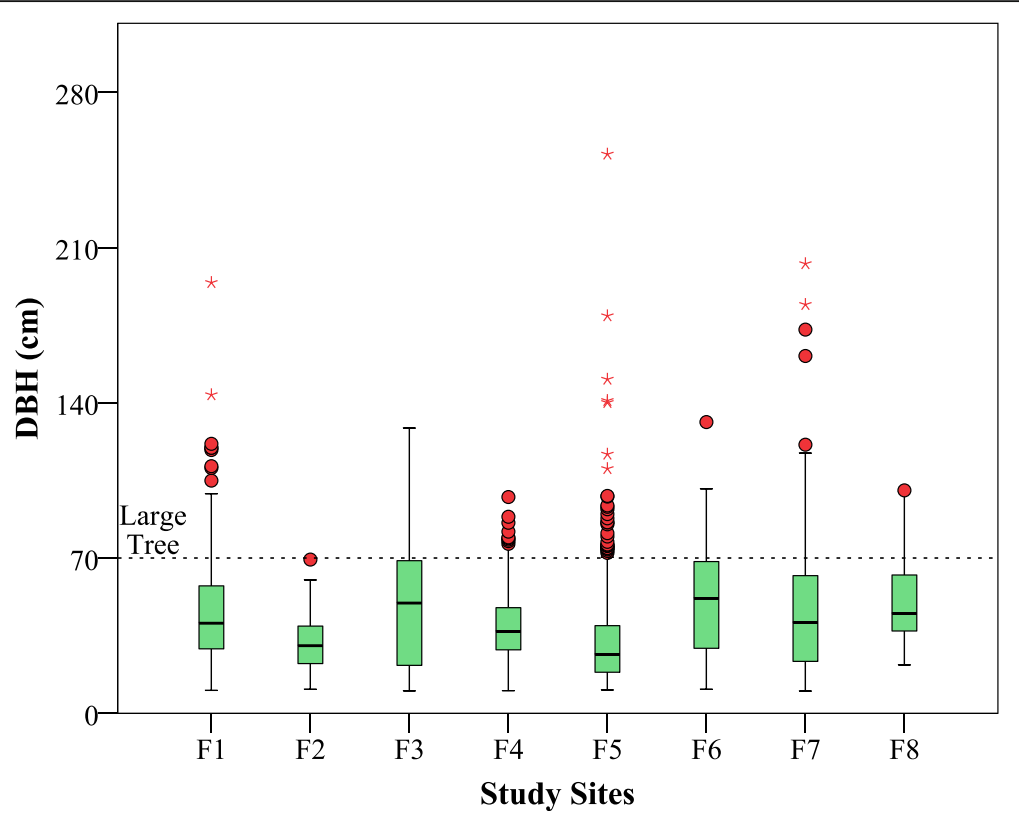

Fig. 3 Box-whisker plot representing median DBH distribution of the study sites. The Horizontal line in the box represents median value, the box represents interquartile $(\mathrm{IQ})$ range (25th-75th percentile), the whiskers represent the highest and lowest values ( $\leq 1.5$ times IQ range), outliers are up to 3 times IQ range, and, extreme outliers beyond this range are represented with an asterisk

indicating uneven distribution of growing stock. The linear regression indicates that species dominance (IVI) explains $70.7 \%$ of the total variation in the growing stock (Fig. 4). Elevation was negatively correlated with MR $(R$ $=-0.502, p 0.25), H^{\prime}(R=-0.464, p=0.25)$, and TCD
$(R=-0.321, p=0.44)$; however, the correlations were non-significant. Large trees stem density showed a significant positive correlation with GSVD $(R=0.754$, $p=0.03)$. Maximum diameter was significantly positively associated with $\operatorname{TBD}(R=0.719, p=0.045)$ and $\operatorname{TCD}(R=$

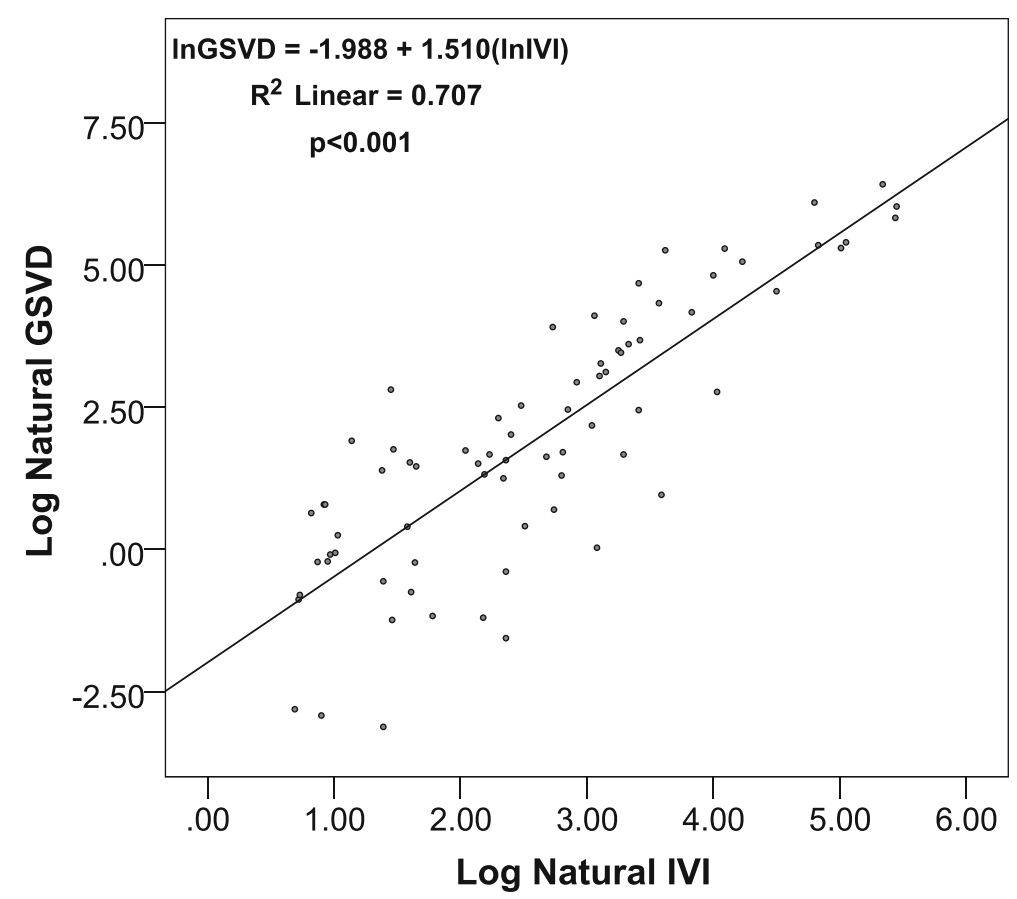

Fig. 4 Linear regression between $\log _{e} I V I$ and $\log _{e}$ GSVD of all the tree species under different forest types 
Table 5 Eigenvalues and cumulative variance explained by components along with loading coefficients and correlation of variables with principal axes

\begin{tabular}{lllll}
\hline Parameter & Component 1 & Component 2 & Component 3 & Component 4 \\
\hline Eigenvalue & 2.65 & 1.15 & 0.19 & 0.01 \\
Cumulative variance (\%) & 66.35 & 28.79 & 4.66 & 0.21 \\
& Loading coefficients & & Loading correlations & PC2 \\
Variable & PC1 & PC2 & PC1 & $\mathbf{0 . 9 5 6}$ \\
LTSD & 0.146 & 0.891 & 0.237 & -0.304 \\
MR & 0.583 & -0.283 & $\mathbf{0 . 9 4 9}$ & -0.225 \\
H' & 0.582 & -0.209 & $\mathbf{0 . 9 4 8}$ & $\mathbf{0 . 8 9 3}$ \\
TBD & 0.548 & 0.287 & $\mathbf{0 . 3 0 7}$ &
\end{tabular}

Loading coefficients of PC1 and PC2 are only represented since these components were the only significant components. Bold loading correlations indicate significant correlations

PC1 principal component 1, PC2 principal component 2, LTSD large tree stem density, MR Margalef richness index, $H^{\prime}$ Shannon-Weiner Diversity Index, TBD total biomass density

$0.716, p=0.046)$. TBA showed significant strong positive correlation with GSVD $(R=0.792, p=0.019)$. TBD showed significant strong positive correlations with TCD $(R=1, p<0.001), \operatorname{TSR}(R=0.719, p=0.044), \mathrm{MR}(R=$ $0.738, p=0.037)$, and $H^{\prime}(R=0.707, p=0.050)$. TCD also showed significant strong positive correlation with $\mathrm{MR}(R$ $=0.720, p=0.044)$. PCA axis 1 (PC1) and axis 2 (PC2) together explain $95.13 \%$ of the cumulative variation in the data (Table 5); moreover, the scree plot indicates that both the components (PC1 and PC2) lie above the elbow and the broken stick model (Fig. 5a); therefore, PCA axis 1 and 2 were significant components (Table 5). The eigenvalues and cumulative variation contributed by each component are represented in Table 5. PCA biplot indicates (Fig. 5b) species richness (MR) and diversity $\left(H^{\prime}\right)$ parameters have large positive loading coefficients (Table 5) with PC1 that explains $66.35 \%$ variation in the data. Large tree density, however, very strongly associates positively with
PC2 (Table 5 and Fig. 5b) which accounts for $28.79 \%$ variance. TBD is correlated only to PC1 along with diversity and richness parameters, not the large tree stem density (Table 5 and Fig. 5b). Therefore, PC1 focuses on the diversity and biomass parameters while the $\mathrm{PC} 2$ regulates the large tree stem density (Table 5 and Fig. 5b).

\section{Discussion}

Association of biomass carbon stock with stand structure and large trees

The biomass distribution between pure and mixed forest stands did not show any trend upon comparison with similar forest types in this study. For instance, Sal mixed forest (F1) had higher biomass density than pure Sal counterpart (F2); however, pure C. deodara forest (F6) had higher biomass density than mixed oak-deodar forest (F4) (Table 4). Under this aspect, population structure and species composition played a significant role.

a
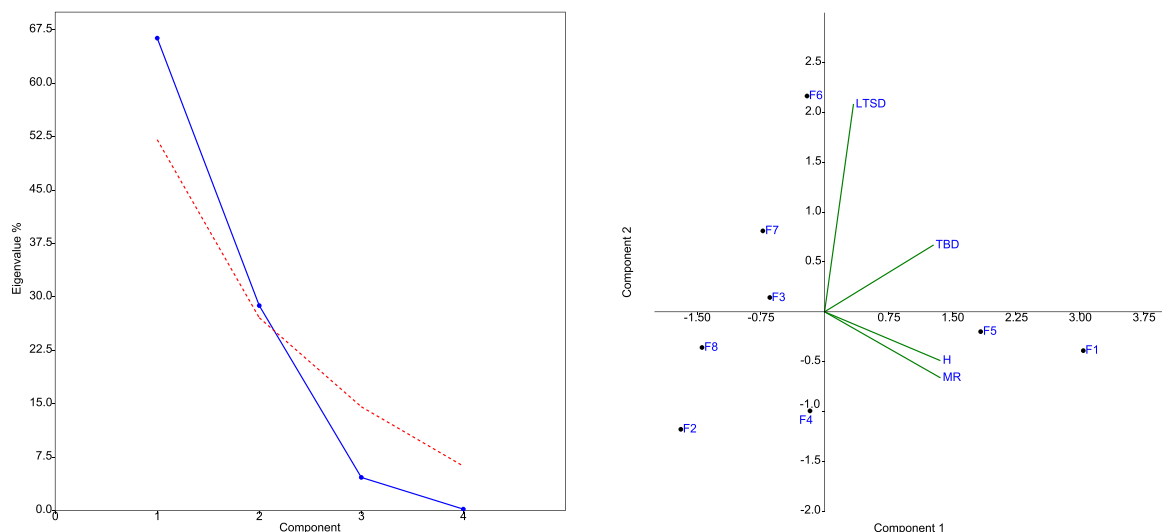

Fig. 5 Representation of PCA analysis. a Scree plot indicating the number of significant principal components. Red dot-dash line indicates the broken stick model, eigenvalues under this curve are non-significant. b PCA bi-plot representing the ordination of sites (F1-F8) and variables (green lines) 
The density-diameter curves (Fig. 2) not only represent the population structure of a forest but also give interpretation over age structure, successional stage, and regeneration status (Rao et al. 1990). Forest types F1, F2, F4, and F8 show lower stem density in the lowest diameter classes (Figs. 2 and 3). This indicates poor regeneration potential in these forests or selective harvest of smaller diameter individuals. Being forest types with climax species viz. S. robusta, Q. oblongata, and A. spectabilis, this loss of regeneration could influence the future carbon stocks of these forests drastically. Previous studies (Singh and Singh 1986; Singh and Singh 1987; Rai et al. 2012) in the region also highlight the regeneration loss. F2 and F4 indicate unimodal stacking of individuals (Fig. 2) in the intermediate DBH classes along with a lower concentration of large trees (Fig. 3). This is further corroborated with the least spread (smaller box) in the box plot analysis (Fig. 3), suggesting that these forests are still maturing and represent even-aged forests having maximum GSVD stacking in intermediate diameter classes. These forests require stringent management since natural or anthropogenic disturbance could diminish the carbon stock of these forests especially F2 wherein $S$. robusta is highly susceptible to pest infestation (Singh and Thapa 1988). Species-specific pest infestations impact the carbon stock of a region immensely, causing the loss of standing biomass. Furthermore, the snags and deadwood thus produced affect the regeneration potential, species composition, carbon pool, and fire dynamics in the region (Lutz et al. 2021). F3, F5, F6, and F7 showed efficient regeneration with maximum GSVD allocation to the larger diameter classes (Figs. 2 and 3).

The most prominent observation from stand structural analysis yields large trees as the chief contributors toward growing stock (Fig. 2). For the even-aged forest stands, the diameter classes with the maximum stem density did not have maximum GSVD (Fig. 3). Our study, therefore, signifies that overall stem density had no relation with either growing stock or biomass carbon stock. Furthermore, a significant positive association of total basal area, stem density of large trees with GSVD, and maximum DBH with TBD and TCD signify the importance of large trees in regulating the growing stock. Thus, the occurrence of trees in the larger diameter classes instead of total stem density is a major stand structural factor regulating the growing stock in these major Central Himalayan forest types. Sharma et al. (2010) also observed no significant correlation between stem density and total carbon density in twenty major forest types of Garhwal Himalayas. In this study, the large trees though constituting only $0-22.3 \%$ of stem density contributed $0-65.1 \%$ of the total GSVD. In Eastern Himalayas, also large trees contributed significantly to biomass carbon stock (Sundriyal and Sharma 1996; Baishya and Barik
2011). The enormous carbon stock of large trees has global recognition. Brown and Lugo (1992) concluded that large trees contributed around $40 \%$ to aboveground biomass in tropical Amazon forest with stem density no more than 3\% of the total. Slik et al. (2013) also reported 25.1-44.5\% biomass allocation to large trees in the Neotropical and Paleotropical forest where such trees occupied no more than $3.8 \%$ of the total stem density. Large trees contributed $33 \%$ of the total biomass in the Australian wet tropical rainforest though being only $2.4 \%$ of total stem density (Bradford and Murphy 2019). This indicates that these large trees are rare in the forest structure, the box-plot also place such individuals as outliers from the general population distribution (Fig. 3). Therefore, the loss of even a single large tree though may not give any pronounced effect over stem density, and may go unnoticed but would reduce the carbon stock of the forest substantially. Furthermore, large trees are regarded as important keystone species in various terrestrial ecosystems, and prevent the establishment of invasive and ruderal species (Gandhi and Sundarapandian 2017; Bradford and Murphy 2019). Luyssaert et al. (2008) and Körner (2017) aptly justified the significance of oldgrowth large trees in maintaining the carbon pool globally as well as acting as efficient global carbon sinks refuting the claim that large trees are not efficient carbon sequesters. There is significance of small and intermediate diameter trees since these individuals would enhance the carbon stock of the forest types with time on account of their higher carbon sequestration potential (Gandhi and Sundarapandian 2017). In our study, we saw the preponderance of intermediate DBH classes in all forest types except F5 and F7 (Fig. 2); this explains lower recruitment and exploitation of higher diameter classes in maturing forests. A similar trend was also observed by Saxena et al. (1984) in Kumaun Himalayas. F5 and F7 indicate decreasing tree density with increasing DBH classes (Fig. 2), and Sundriyal and Sharma (1996) regarded such a trend as a sign of healthy forest structure.

ANOVA results show between groups (quadrats) variability among all sub-tropical (F3) and temperate (F4F7) forest types, also visualized by broader IQ range for these zones (Fig. 3). Uneven distribution of large trees predominantly causes such heterogeneity. Similar observations were also reported by Gandhi and Sundarapandian (2017) in the tropical dry deciduous forest of Eastern Ghats, India. Thus, even the slightest destruction on account of anthropogenic activity could lead to greater carbon stock loss for such forests.

\section{Association of biomass carbon stock with species diversity}

Species composition plays a vital role in modulating forest carbon stocks. Negi et al. (2003) reported maximum 
carbon allocation in the conifer woods followed by dicot deciduous and dicot evergreen species. This pattern is evident since the top ten species in order of TCD (Supplementary Table S3) are either conifers or dicot deciduous. Oaks being evergreen still have a higher carbon content in their wood along with a longer rotation period as compared to other evergreen species leading to higher TCD (Sharma et al. 2010). The total species richness recorded in this study (4-21 species) is within the range reported (7-22 species) for Garhwal Himalayas (Sharma et al. 2018). Our diversity $\left(H^{\prime}\right)$ value $(0.77-2.63)$ was higher than the values reported $(0.28-$ 1.75) for major forest types of Garhwal Himalayas (Sharma et al. 2010). Since the study sites fall under reserved forests, wildlife sanctuary, and national park, therefore, the anthropogenic disturbance is quite limited thereby realizing the true diversity potential of the region. The regression analysis (Fig. 4) indicates the importance of species dominance as a predictor in growing stock contribution. IVI incorporates the three major components of a species viz. relative density, relative frequency, and relative basal area, therefore IVI gives a true sense of species dominance to a species relative to its population. This relation justifies the organization of species in decreasing order of TCD contribution (Supplementary Table S3) since the top-level species are either dominant or co-dominant species for different forest types. This relation is significant under forest management since basic phytosociology could identify prominent species that could be earmarked for conservation and afforestation plans.

In our study, just $9.4 \%$ of the total species accounted for $50.6 \%$ of the TCD in the study (Supplementary Table S3). Corollary to this in the Amazonian forest just $1 \%$ of the total species account for $50 \%$ of the total carbon stock and productivity (Fauset et al. 2015). This indicates that there is biomass hyperdominance in these major Central Himalayan forest types. Biomass hyperdominance is a concept wherein a small number of species have a disproportionate effect on total biomass and productivity (Fauset et al. 2015). Such species thus become indispensable under management implications. Our results also indicate a strong significant positive correlation between species richness, diversity, and biomass density. Gogoi et al. (2020) in Eastern Himalayas reported a weak positive association between species diversity $\left(H^{\prime}\right)$ and TCD $\left(R^{2}=0.25, p<0.05\right)$. Behera et al. (2017) reported strong positive correlation between species richness, species diversity, and above-ground biomass in Indian tropical deciduous forests with S. robusta and Tectona grandis as major elements. Several investigators have also shown a positive relationship between species richness and biomass globally (Day et al. 2014; Mensah et al. 2016; Zhang et al. 2017; Sintayehu et al.
2020). This association of biomass with species diversity is mutually beneficial for conservation, and plays a key role under management implication. Any management plan must not only focus on biomass enrichment but also aim to maintain if not enrich the biodiversity. In this regard, monospecific plantations would harm the ecosystem functions of such forests. Furthermore, with appropriate management strategies, the forest types studied provide co-benefit of biomass and biodiversity enhancement. It is recommended to consider the prominent native species for each forest type along with endemic and threatened Himalayan species for management practices. In recent times, exotic and commercial species such as $T$. grandis, Eucalyptus sp., $P$. roxburghii are being given more preference over the native species for management purposes (Singh and Singh 1987). These species have a smaller rotation period than their counterparts like $S$. robusta and oaks (Sharma et al. 2010), thus such management efforts would yield only short-term carbon gains on the cost of long-term carbon storage and biodiversity.

The results from PCA analysis (Fig. 5 and Table 5) signify the role of both large tree density and species diversity in influencing the ordination of study sites. F1 and F5 cluster together in the positive direction of PC 1 since they have maximum diversity, species richness, and TBD (Fig. 5b). Therefore, in these sites, management of diversity is crucial for securing carbon stock. Sites F6, F7, and F3 ordinate in the positive plane of PC2 having a maximum correlation with large tree stem density (Fig. 5b). These sites thus require stringent management to secure large trees to preserve the carbon stock; moreover, these sites represent poor species richness and diversity. Management strategies could focus on this aspect too. Sites F2, F8, and F4 club in the bottom left quadrant indicating that these sites have the lowest values for all the variables as all the variables point in the positive and increasing values of components (Fig. 5b). These sites require special attention, the management strategy for such regions require focus for the preservation of natural regeneration, enrichment of diversity through plantations, and preservation of existing large diameter trees. Sintayehu et al. (2020) reported that functional diversity traits (maximum DBH, maximum tree height, wood density) are more strongly correlated with Ethiopian woodland aboveground biomass than species diversity components. Based on this, they considered that the natural ecosystems might have achieved their species richness potential. In our study, both the functional traits (maximum DBH) and species richness traits correlate significantly with biomass, indicating that our forests can still accommodate more species. Therefore, management implications can aim in enhancing the biodiversity of forest stands which would concurrently enhance the carbon stocks. Our PCA 
Table 6 Comparative review between biomass and carbon stock estimates in similar forest types reported under previous investigations and the present study

\begin{tabular}{|c|c|c|c|c|c|}
\hline Region $^{\text {Reference }}$ & Comment & AGBD & AGCD & TBD & TCD \\
\hline \multicolumn{6}{|c|}{ Tropical to sub-tropical forests with presence of S. robusta } \\
\hline Present study (F1 and F2) & Mixed and pure S. robusta dominant forest & $\begin{array}{l}457.1- \\
1001.8\end{array}$ & $\begin{array}{l}208.5- \\
451.9\end{array}$ & $\begin{array}{l}566.2- \\
1280.8\end{array}$ & $\begin{array}{l}258.2- \\
577.8\end{array}$ \\
\hline Nepal $^{1}$ & No correlation between species richness and biomass carbon & - & - & $254 \pm 72$ & $120 \pm 34$ \\
\hline Cambodia $^{2}$ & Biomass carbon of tropical evergreen and semi-evergreen forest & - & - & - & $\begin{array}{l}163.8 \pm \\
7.8\end{array}$ \\
\hline Tripura $^{3}$ & No correlation between species diversity and biomass & $\begin{array}{l}110.5- \\
179.9\end{array}$ & $55.3-89.9$ & $\begin{array}{l}139.3- \\
226.6\end{array}$ & $\begin{array}{l}167.6- \\
219.7\end{array}$ \\
\hline Meghalaya $^{4}$ & Tropical semi-evergreen Sal plantation & 406.0 & 203.2 & - & - \\
\hline Meghalaya $^{5}$ & Primary tropical old-growth forest & 323.7 & 158.4 & 374.5 & 182.3 \\
\hline $\begin{array}{l}\text { Uttarakhand } \\
\text { (Dehradun) }\end{array}$ & Moist deciduous Shiwalik Sal forest & $\begin{array}{l}268.6- \\
347.7\end{array}$ & - & $\begin{array}{l}338.4- \\
438.2\end{array}$ & $\begin{array}{l}169.2- \\
219.1\end{array}$ \\
\hline $\begin{array}{l}\text { Uttarakhand } \\
\text { (Pauri Garhwal) }\end{array}$ & Negative correlation between species diversity and total carbon density & $\begin{array}{l}279.6 \pm \\
37.6\end{array}$ & - & $\begin{array}{l}346.5 \pm \\
45.5\end{array}$ & $\begin{array}{l}159.4 \pm \\
20.9\end{array}$ \\
\hline \multicolumn{6}{|l|}{ Sub-tropical Pine forest } \\
\hline Present study F3 & P. roxburghii and A. nepalensis association forest & 471.8 & 215.7 & 596.2 & 272.5 \\
\hline Nepal ${ }^{8}$ & Sub-tropical pine forest & 86.0 & 38.7 & - & - \\
\hline Nepal $^{9}$ & $\begin{array}{l}\text { Monospecific forest stands had higher biomass carbon than mixed } \\
\text { stands }\end{array}$ & - & $89.6 \pm 7.4$ & - & - \\
\hline China $^{10}$ & Six forest types with Pinus elements & - & - & $51.8-120.5$ & - \\
\hline Korea $^{11}$ & 74-year-old P. koraiensis plantation & 339.9 & - & - & - \\
\hline USA, Wyoming ${ }^{12}$ & Unmanaged $P$. ponderosa forest & 185.4 & - & - & - \\
\hline Meghalaya $^{13}$ & Old-growth P. kesiya forest & 419.7 & 205.7 & 460.5 & 224.4 \\
\hline Meghalaya $^{14}$ & Weak positive correlation between tree species diversity and biomass & - & - & - & $63-74.7$ \\
\hline $\begin{array}{l}\text { Uttarakhand }{ }^{15} \text { (Pauri } \\
\text { Garhwal) }\end{array}$ & Van Panchayat managed non-degraded pine forest & 790.5 & - & - & 490.3 \\
\hline Uttarakhand ${ }^{16}$ (Garhwal) & Old-growth forest & $363.4 \pm 9.9$ & $\begin{array}{l}167.2 \pm \\
4.6\end{array}$ & $447.7 \pm 12$ & $\begin{array}{l}205.9 \pm \\
5.5\end{array}$ \\
\hline Uttarakhand ${ }^{17}$ (Kumaon) & Monospecific $P$. roxburghii forest & - & - & $\begin{array}{l}210.8 \pm \\
36.6\end{array}$ & - \\
\hline \multicolumn{6}{|l|}{ Temperate forests } \\
\hline Present study (F4-F7) & $\begin{array}{l}\text { Ban oak forest, temperate deciduous forest, Moist deodar forest and } \\
\text { Kharsu Oak forest }\end{array}$ & $\begin{array}{l}499.4- \\
758.8\end{array}$ & $\begin{array}{l}229.1- \\
350.2\end{array}$ & $\begin{array}{l}634.2- \\
968.6\end{array}$ & $\begin{array}{l}290.9- \\
437.5\end{array}$ \\
\hline Belgium ${ }^{18}$ & Temperate forest & - & - & - & 101.0 \\
\hline USA ${ }^{19}$ & Mid-Atlantic temperate forests & $81-266$ & - & $101-326$ & - \\
\hline USA, Kentucky ${ }^{20}$ & 90-year-old second growth temperate mixed deciduous forest & $\begin{array}{l}108.3- \\
111.0\end{array}$ & - & - & - \\
\hline Jammu and Kashmir ${ }^{21}$ & C. deodara dominant forest & $\begin{array}{l}393.7 \pm \\
221.3\end{array}$ & - & $\begin{array}{l}496.7 \pm \\
278.9\end{array}$ & - \\
\hline Manipur ${ }^{22}$ & Largest sacred grove in Manipur, India & $\begin{array}{l}962.9- \\
1130.8\end{array}$ & $\begin{array}{l}481.5- \\
565.4\end{array}$ & - & - \\
\hline Uttarakhand ${ }^{23}$ (Kumaon) & Q. oblongata forest & - & - & $\begin{array}{l}387.3 \pm \\
43.9\end{array}$ & \\
\hline Uttarakhand ${ }^{24}$ (Garhwal) & Ridge top Q. oblongata forest & - & - & 497.32 & 228.75 \\
\hline Uttarakhand ${ }^{25}$ (Kumaon) & Temperate deciduous A. indica forest & 397.2 & - & 501.8 & - \\
\hline Uttarakhand ${ }^{16}$ (Garhwal) & Old-growth temperate deciduous $A$. indica forest & $\begin{array}{l}429.8 \pm \\
14.6\end{array}$ & $\begin{array}{l}193.4 \pm \\
6.6\end{array}$ & $\begin{array}{l}527.6 \pm \\
17.5\end{array}$ & $\begin{array}{l}237.4 \pm \\
7.8\end{array}$ \\
\hline Uttarakhand ${ }^{16}$ (Garhwal) & Old-growth temperate C. deodara forest & $\begin{array}{l}546.7 \pm \\
20.5\end{array}$ & $\begin{array}{l}251.5 \pm \\
9.4\end{array}$ & $\begin{array}{l}667.6 \pm \\
24.5\end{array}$ & $\begin{array}{l}307.1 \pm \\
11.3\end{array}$ \\
\hline
\end{tabular}


Table 6 Comparative review between biomass and carbon stock estimates in similar forest types reported under previous investigations and the present study (Continued)

\begin{tabular}{|c|c|c|c|c|c|}
\hline Region ${ }^{\text {Reference }}$ & Comment & AGBD & AGCD & TBD & TCD \\
\hline \multicolumn{6}{|c|}{ Tropical to sub-tropical forests with presence of S. robusta } \\
\hline Uttarakhand ${ }^{26}$ (Garhwal) & Q. semecarpifolia dominant forests & - & $\begin{array}{l}136.9- \\
221.4\end{array}$ & - & $\begin{array}{l}179.6- \\
285.9\end{array}$ \\
\hline Uttarakhand ${ }^{27}$ (Garhwal) & $\begin{array}{l}\text { Q. semecarpifolia dominant forest with northern slopes having greater } \\
\text { biomass }\end{array}$ & $\begin{array}{l}190.5- \\
287.1\end{array}$ & - & $\begin{array}{l}238.2- \\
355.7\end{array}$ & $\begin{array}{l}107.2- \\
160.1\end{array}$ \\
\hline Uttarakhand ${ }^{25}$ (Kumaon) & Temperate $Q$. semecarpifolia dominant forest & 459.7 & - & 590.2 & - \\
\hline Uttarakhand ${ }^{28}$ (Tehri) & Sem Mukhem sacred forest & 1224.9 & & 1549.7 & 774.8 \\
\hline \multicolumn{6}{|l|}{ Sub-alpine forest } \\
\hline Present study F8 & A. spectabilis dominant forest & 485.9 & 223.8 & 607.9 & 279.9 \\
\hline Poland ${ }^{29}$ & A. alba dominant forest & $0.3-293.6$ & - & - & - \\
\hline$U_{S A}^{30}$ & Old-growth A. amabilis forest & 464.8 & - & - & - \\
\hline Sikkim ${ }^{31}$ & $\begin{array}{l}\text { Species diversity and richness have positive relation with biomass } \\
\text { carbon }\end{array}$ & 191.3 & - & - & 134.2 \\
\hline Uttarakhand ${ }^{32}$ (Garhwal) & Treeline ecotone forest & - & - & $32-387$ & - \\
\hline
\end{tabular}

AGBD: $\mathrm{Mg} \mathrm{ha}^{-1} ; \mathrm{AGCD}: \mathrm{Mg} \mathrm{C}_{\mathrm{Ca}}{ }^{-1} ; \mathrm{TBD}: \mathrm{Mg} \mathrm{ha}^{-1}$; and TCD: $\mathrm{Mg} \mathrm{Cha}^{-1}$

References: 1: Thapa Magar and Shrestha 2015; 2: Samreth et al. 2012; 3: Banik et al. 2018; 4: Baishya et al. 2009; 5: Baishya and Barik 2015; 6: Shahid and Joshi 2015; 7: Sharma et al. 2010; 8: Baral et al. 2009; 9: Pariyar et al. 2019; 10: Guo et al. 2010; 11: Son et al. 2007; 12: Tinker et al. 2010; 13: Baishya and Barik 2011; 14: Gogoi et al. 2020; 15: Vikrant and Chauhan 2014; 16: Dimri et al. 2017a; 17: Chaturvedi and Singh 1987; 18: Walle et al. 2005; 19: Jenkins et al. 2001; 20: Newman et al. 2006; 21: Dar and Sahu 2018; 22: Waikhom et al. 2018; 23: Rawat and Singh 1988; 24: Sharma et al. 2016; 25: Adhikari et al. 1995; 26: Dimri et al. 2017a b; 27: Sharma et al., 2011; 28: Pala et al. 2013; 29: Jagodziński et al. 2019; 30: Turner and Singer 1976; 31: Rai et al. 2018; and 32: Rai et al. 2020

findings were comparable to Day et al. (2014) in the Central African rainforest; however, their second PCA component had a significant correlation between stem density and biomass. This indicates that different sites have different factors that yield maximum biomass production.

The two most predominant mechanisms elucidated for the effect of species richness over biomass are complementarity effects (diverse species have different niche requirements leading to resource partitioning thus leading to maximum resource utilization and enhanced productivity) and selection effects (enhanced productivity on account of the dominance of species with specific traits) (Loreau and Hector 2001; Cardinale et al. 2007). Under our observations, not only a few dominant species and species with larger diameter contribute to biomass carbon stocks but the species diversity and richness are also positively associated. Thus, these forest types have a complex interplay of both mechanisms. Similar results were reported by Cavanaugh et al. (2014) on a global scale. We, however, do not generalize our findings to Central Himalayas since we did not consider all the forest types present in the region, and on account of the smaller sample size. Zhang et al. (2017) also emphasized that positive species diversity and biomass relationships though ubiquitous across all vegetation strata; however, the overstorey diversity and biomass profoundly impact the understorey biomass predominantly through resource filtering. This study would help researchers focusing on understorey diversity and biomass relations in the region. Furthermore, the relationship between species diversity and biomass is inconsistent; there were reports of negative to no significant association between species diversity and biomass within the region (Sharma et al. 2010; Gairola et al. 2011), in India (Sahu et al. 2016; Behera et al. 2017; Gandhi and Sundarapandian 2017) and the world (Jacob et al. 2010; Szwagrzyk and Gazda 2007). Therefore, on a regional scale, such studies are imperative for deciphering adequate management strategies since the associations between variables might get diluted in large-scale studies thereafter hindering forest management and carbon stock enhancement at the regional scale.

\section{Variations in biomass carbon stocks}

The segregation of TBD into above and belowground components showed a distinct pattern in all the forest types. The ccontribution of AGBD (79.6\%) and BGBD (20.4\%) to the TBD in the present study is comparable to the value reported (78.54\% AGBD and 21.46\% BGBD) by Sharma et al. (2018) for Garhwal Himalayas, (79\% AGBD and 21\% BGBD) for pan-India biomass (Chhabra et al. 2002), and Brazilian Amazon tropical moist forest (10-50\% by BGBD) (Brown and Lugo 1992). Lower contribution by belowground biomass is normal since plants invest in belowground biomass significantly only under stressful conditions. 
In our study, elevation had a negative association with stem density, species richness, species diversity, TBD, and TCD; however, the associations were not significant. Singh et al. (1994) reported that elevation had a significant negative association with stem density, species richness, species diversity, and biomass in the Central Himalayan forest types. Since we selected predominant Central Himalayan forest types and not all within the elevational range therefore, our trends with elevation were not significant. At elevations around 2800-2900 m, we saw a spike in stem density, basal area, and biomass due to much-branched Krumholtz like growth of $R$. arboreum in these elevations which forms a major under canopy tree layer contributing significantly to stem density, basal area, and biomass (Singh et al. 1994; Rai et al. 2018). The treeline ecotone forest F8 depicts lower values across all parameters since these forests form a limit of closed-canopy forests, and only a few species acclimated to the harsh alpine conditions thrive at such elevations. Furthermore, new recruitment in A. spectabilis dominant Tungnath (F8) treeline ecotone is sparse which is reflected in the population structure also (Fig. 2) (Rai et al. 2012). Stringent management approach is deemed necessary in such regions to facilitate and conserve natural regeneration to preserve treeline carbon stock. Sub-tropical pine forest (F2) recorded the lowest carbon stock in our elevational range since these forests are inflicted with forest fires which limit their productivity and affect regeneration (Sharma et al. 2010). On average, temperate forest types had higher carbon stock due to the presence of mature to old-growth large-diameter hardwood and conifer trees (Dimri et al. 2017a).

The estimates for growing stock, biomass, and carbon stock though give a quantitative measure to compare the forest types; however, the state of the forests could only be visualized upon comparing the results with similar forest types. Our biomass and carbon stocks were higher or within the range as reported by previous investigators (Table 6). Our estimates were most comparable with either mature old-growth forests, community-managed forests, or sacred grooves (Table 6). These forests are pristine undisturbed forests representing the true potential of biomass and carbon stock in the region. Such forests are used as control sites in biomass modeling studies (Osuri et al. 2014). This study, therefore, elucidates that the selected predominant Central Himalayan forest types have huge biomass carbon stock and thus, require protection from anthropogenic activities.

\section{Conclusions}

The knowledge under growing stock provides quantitative value to the forest land helping forest managers to delineate regions as carbon-rich or deficient, and proceed accordingly. Results from quantitative stand structural attributes implicate predominant Himalayan climax species and forest types have a preponderance of intermediate $\mathrm{DBH}$ class along with a significant decline in new recruitment. The total basal area, the density of large trees, and maximum $\mathrm{DBH}$ are key stand structural factors that regulate the biomass carbon stock. Large trees although low in abundance (up to $22 \%$ ) were key contributors to the total biomass (up to 65\%). Though species richness and diversity correlated significantly with biomass carbon density only a handful of species (9.4\%) contributed more than $50 \%$ of the total biomass indicating biomass hyperdominance. The biomass distribution was also heterogeneous within the forest types, and species dominance regulate the growing stock directly. Elevation did not show significant correlations indicating that the entire elevational range has huge carbon stock. Regulation of biomass carbon by both structural and diversity components suggest a complex interplay of complementarity effects and selection effect that enhance the carbon stock of the region. The comparative review illustrates that these Central Himalayan forest types are carbon-rich and represent stock equivalent to sacred grooves and communitymanaged forests where communities preserve the forest resources.

Under management implications, we recommend that for any timber requirements the small diameter trees are a viable alternative since they have greater stem density and lower contribution towards growing stock. However, sustainable utilization is necessary since these individuals represent future carbon stock security. For further enhancing the carbon security, the preservation as well as supplementing the natural regeneration is pertinent. For conservation of present carbon stock, the large trees require special focus in the region. Tagging and enumeration of these individuals will secure their conservation. The deadwood large trees are also vital ecosystem components and support essential ecological processes. Uniform implementation of forest management within an area is essential since there is heterogeneity in biomass distribution thus, creating biomass hotspots, and any disturbance especially in the peripheral areas of protected regions close to habitations could lead to significant loss. All management strategies require focus over both biomass and diversity enhancement, monospecific strategies are not a viable option. The management of these regions by forest authorities alone is not sufficient; the co-operation from local communities is a key necessity. Therefore, sensitization of local communities for sustainable use of forest resources along with enhancement of forest biodiversity is crucial. Further research is required for 
generalization of results, especially incorporating all the forest types along entire elevational gradients.

\section{Supplementary information}

The online version contains supplementary material available at https://doi. org/10.1186/s13717-021-00283-8

Additional file 1 Supplementary Table S1. GPS coordinates and elevational range of the quadrats laid under different forest types. Supplementary Table S2. Percentage distribution of stem density and total carbon density of different species in studied forest types. Supplementary Table S3. Total carbon density of all the 53 tree species arranged in order of decreasing TCD. Values in parenthesis indicate relative percentage

\begin{abstract}
Abbreviations
AGBD: Aboveground biomass density; AGCD: Aboveground carbon density; ANOVA: Analysis of variance; ASA: Asarori; BEF: Biomass expansion factor; BGBD: Belowground biomass density; $\mathrm{CBH}$ : Circumference at breast height; CHK: Chakrata; CHP: Chopta; DBH: Diameter at breast height; FSI: Forest survey of India; GA: Geographic area; GON: Gondar; GPS: Global positioning system; GSVD: Growing stock volume density; H': Shannon-Wiener diversity index; HHC: Higher Himalayan crystalline; IHR: Indian Himalayan region; IQ: Inter-quartile; IVI: Importance value index; KAN: Kanasar; LH: Lesser Himalaya; MR: Margalef's Richness Index; NPP: Net primary productivity; PC: Principal component; PCA: Principle component analysis; Pg: Peta gram; RNP: Rajaji national park; SD: Stem density; SH: Sub-Himalayan; TBA: Total basal area; TBD: Total biomass density; TCD: Total carbon density; TSR: Total species richness; TUN: Tungnath; TYN: Triyuginarayan; UNFCCC: United Nations framework convention on climate change
\end{abstract}

\section{Acknowledgements}

The authors are thankful to the PCCF \& CWLW, Uttarakhand Forest Department along with Director Rajaji National Park and DFOs of Dehradun, Chakrata and Kedarnath Wildlife Sanctuary for granting the necessary field research permission. Support from Aakash Goswami, Ravi Kumar, and Anshu Siwach during field inventory is highly acknowledged. The authors also acknowledge the two anonymous reviewers and the associate editor for their valuable and constructive comments and suggestions which helped in shaping this manuscript.

\section{Availability of data and materia}

All data generated or analyzed during this study are included in this published article and its supplementary information files (S1-S3).

\section{Authors' contributions}

RB: conceptualization, writing-reviewing and editing, supervision, project administration, funding acquisition. SK: methodology, formal analysis, investigation, resources, writing —original draft. All authors read and approved the final manuscript.

\section{Funding}

Ratul Baishya acknowledges the complete financial assistance provided by SERB, Govt. of India in the form of a research project (SERB Project: EEQ/ 2016/000164). Siddhartha Kaushal thanks UGC, Delhi for providing financial assistance in the form of CSIR-UGC JRF. Additional fund received form IOE, University of Delhi as Faculty Research Programme (FRP) grant (2020-2021) is highly acknowledged.

\section{Ethics approval and consent to participate}

Not applicable.

\section{Consent for publication}

Not applicable.

\section{Competing interests}

The authors declare that they have no competing interests
Received: 26 November 2020 Accepted: 31 January 2021

Published online: 20 February 2021

\section{References}

Adhikari BS, Rawat YS, Singh SP (1995) Structure and function of high-altitude forests of central Himalaya I. Dry matter dynamics. Ann Bot 75(3):237-248

Agarwal SK (2017) Flora of Jaunsar Bawar (Chakrata Hills, Western Himalaya) with Ethanobotanical Notes. Bishen Singh Mahendra Pal Singh, Dehradun

Baishya R, Barik SK (2011) Estimation of tree biomass, carbon pool and net primary production of an old-growth Pinus kesiya Royle ex. Gordon forest in north-eastern India. Ann For Sci 68(4):727-736. https://doi.org/10.1007/s13 595-011-0089-8

Baishya R, Barik SK (2015) Ecosystem level carbon and net primary productivity of an old-growth and a regenerating humid tropical forest of North-Eastern India. Int J Plant Environ 1(1). https://doi.org/10.18811/ijpen.v1i1.7117

Baishya R, Barik SK, Upadhaya K (2009) Distribution pattern of aboveground biomass in natural and plantation forests of humid tropics in northeast India. Trop Ecol 50(2):295-304

Banik B, Deb D, Deb S, Datta BK (2018) Assessment of biomass and carbon stock in Sal (Shorea robusta Gaertn.) forests under two management regimes in Tripura, Northeast India. J For Environ Sci 34(3):209-223

Baral SK, Malla R, Ranabhat S (2009) Above-ground carbon stock assessment in different forest types of Nepal. Banko Janakari 19(2):10-14

Behera SK, Sahu N, Mishra AK, Bargali SS, Behera MD, Tuli R (2017) Aboveground biomass and carbon stock assessment in Indian tropical deciduous forest and relationship with stand structural attributes. Ecol Eng 99:513-524

Bhattarai KR, Vetaas OR, Grytnes JA (2004) Relationship between plant species richness and biomass in an arid sub-alpine grassland of the central Himalayas, Nepal. Folia Geobot 39(1):57-71

Bradford M, Murphy HT (2019) The importance of large-diameter trees in the wet tropical rainforests of Australia. PLoS One 14(5):e0208377. https://doi.org/1 0.1371/journal.pone.0208377

Brown S, Iverson LR (1992) Biomass estimates for tropical forests. World Resource Review 4(3):366-384

Brown S, Lugo AE (1992) Aboveground biomass estimates for tropical moist forests of the Brazilian Amazon. Interciencia 17(1):8-18

Brown SL, Schroeder P, Kern JS (1999) Spatial distribution of biomass in forests of the eastern USA. For Ecol Manag 123(1):81-90. https://doi.org/10.1016/S03 78-1127(99)00017-1

Cairns MA, Brown S, Helmer EH, Baumgardner GA (1997) Root biomass allocation in the world's upland forests. Oecologia 111(1):1-11. https://doi.org/10.1007/ s00442005020

Cardinale BJ, Wright JP, Cadotte MW, Carroll IT, Hector A, Srivastava DS, Loreau M, Weis JJ (2007) Impacts of plant diversity on biomass production increase through time because of species complementarity. Proc Natl Acad Sci 104(46):18123-18128. https://doi.org/10.1073/pnas.0709069104

Cavanaugh KC, Gosnell JS, Davis SL, Ahumada J, Boundja P, Clark DB et al (2014) Carbon storage in tropical forests correlates with taxonomic diversity and functional dominance on a global scale. Glob Ecol Biogeogr 23(5):563-573. https://doi.org/10.1111/geb.12143

Champion HG, Seth SK (1968) Revised survey of forest types in India. Manager of Publication, Government of India, New Delhi

Chaturvedi OP, Singh JS (1987) The structure and function of pine forest in Central Himalaya. I. Dry matter dynamics. Ann Bot 60(3):237-252

Chhabra A, Palria S, Dadhwal VK (2002) Growing stock-based forest biomass estimate for India. Biomass Bioenergy 22(3):187-194. https://doi.org/10.1016/ S0961-9534(01)00068-X

Chu S (2009) Carbon capture and sequestration. Science 325(5948):1599. https:// doi.org/10.1126/science.1181637

Dar DA, Sahu P (2018) Assessment of biomass and carbon stock in temperate forests of Northern Kashmir Himalaya, India. Proc Int Acad Ecol Environ Sci $8(2): 139-150$

Day M, Baldauf C, Rutishauser E, Sunderland TC (2014) Relationships between tree species diversity and above-ground biomass in Central African rainforests: implications for REDD. Environ Conserv 41(1):64-72. https://doi. org/10.1017/S0376892913000295

Dimri S, Baluni P, Sharma CM (2017) Biomass production and carbon storage potential of selected old-growth temperate forests in Garhwal Himalaya, India. Proc Nat Acad Sci, India Sec B: Biol Sci 87:1327-1333. https://doi.org/1 0.1007/s40011-016-0708-0 
Dimri S, Baluni P, Sharma CM (2017a) Carbon dynamics in Quercus semecarpifolia (Kharsu Oak) and Quercus floribunda (Moru Oak) Forests of Garhwal Himalaya, India. Proc Nat Acad Sci, India Sec B: Biol Sci 88(3):1157-1168

Dlugokencky E, Tans P (2020) Trends in atmospheric carbon dioxide. NOAA/ESRL. https://www.esrl.noaa.gov/gmd/ccgg/trends/

Energy Statistics (2020) National Statistical Office. Ministry of Statistics and Programme Implementation. Government of India, New Delhi

FAO and UNEP (2020) The State of the World's Forests 2020. Forests, biodiversity and people. Rome. doi:https://doi.org/10.4060/ca8642en

Fauset S, Johnson MO, Gloor M, Baker TR, Monteagudo A, Brienen RJ et al (2015) Hyperdominance in Amazonian forest carbon cycling. Nat Commun 6:6857. https://doi.org/10.1038/ncomms7857

FSI (1996) Volume equations for forests of India, Nepal and Bhutan. Forest Survey of India, Ministry of Environment and Forests, Government of India

FSI (2002) The manual of Instruction for field Inventory. Forest Survey of India, Dehradun

FSI (2011) Carbon Stock in India's Forests. Forest Survey of India, Ministry of Environment and Forests, Government of India. Dehradun

FSI (2019) India State of Forest Report 2019. FSI (MoEF), Dehradun

Gairola S, Sharma CM, Ghildiyal SK, Suyal S (2011) Live tree biomass and carbon variation along an altitudinal gradient in moist temperate valley slopes of the Garhwal Himalaya (India). Curr Sci 100(12):1862-1870

Gandhi DS, Sundarapandian S (2017) Large-scale carbon stock assessment of woody vegetation in tropical dry deciduous forest of Sathanur reserve forest, Eastern Ghats, India. Environ Monit Assess 189(4):187. https://doi.org/10.1007/ s10661-017-5899-1

Gaur RD (1999) Flora of the District Garhwal. North West Himalaya, Transmedia

Gibson L, Lee TM, Koh LP, Brook BW, Gardner TA, Barlow J et al (2011) Primary forests are irreplaceable for sustaining tropical biodiversity. Nature 478(7369): 378-381

Gogoi RR, Adhikari D, Upadhaya K, Barik SK (2020) Tree diversity and carbon stock in a subtropical broadleaved forest are greater than a subtropical pine forest occurring in similar elevation of Meghalaya, north-eastern India. Trop Ecol 61: 142-149. https://doi.org/10.1007/s42965-020-00061-1

Guo Z, Fang J, Pan Y, Birdsey R (2010) Inventory-based estimates of forest biomass carbon stocks in China: A comparison of three methods. For Ecol Manag 259(7):1225-1231. https://doi.org/10.1016/j.foreco.2009.09.047

Jacob M, Leuschner C, Thomas FM (2010) Productivity of temperate broad-leaved forest stands differing in tree species diversity. Ann For Sci 67(5):503. https:// doi.org/10.1051/forest/2010005

Jagodziński AM, Dyderski MK, Gęsikiewicz K, Horodecki P (2019) Tree and stand level estimations of Abies alba Mill. aboveground biomass. Ann For Sci 76(2): 56. https://doi.org/10.1007/s13595-019-0842-y

Jenkins JC, Birdsey RA, Pan Y (2001) Biomass and NPP estimation for the MidAtlantic region (USA) using plot-level forest inventory data. Ecol Appl 11(4): 1174-1193. https://doi.org/10.1890/1051-0761(2001)011[1174:BANEFT]2.0.CO;2

Kafaltia H, Kafaltia G (2019) A Comprehensive Study of Uttarakhand. Notion Press, Chennai

Körner C (2017) A matter of tree longevity. Science 355(6321):130-131

Lal R (2008) Carbon sequestration. Philos Trans R Soc B: Biol Sci 363(1492):815830. https://doi.org/10.1098/rstb.2007.2185

Li S, Su J, Lang X, Liu W, Ou G (2018) Positive relationship between species richness and aboveground biomass across forest strata in a primary Pinus kesiya forest. Sci Rep 8:2227

Loreau M, Hector A (2001) Partitioning selection and complementarity in biodiversity experiments. Nature 412(6842):72-76

Lorenz K, Lal R (2010) Carbon sequestration in forest ecosystems. Springer Science \& Business Media. https://doi.org/10.1007/978-90-481-3266-9

Lutz JA, Furniss TJ, Johnson DJ, Davies SJ, Allen D, Alonso A et al (2018) Global importance of large-diameter trees. Glob Ecol Biogeogr 27(7):849-864

Lutz JA, Larson AJ, Freund JA, Swanson ME, Bible KJ (2013) The importance of large-diameter trees to forest structural heterogeneity. PLoS One 8(12): e82784. https://doi.org/10.1371/journal.pone.0082784

Lutz JA, Struckman S, Furniss TJ, Birch JD, Yocom LL, McAvoy DJ (2021) Largediameter trees, snags, and deadwood in southern Utah, USA. Ecol Process 10: 9. https://doi.org/10.1186/s13717-020-00275-0

Luyssaert S, Schulze ED, Börner A, Knohl A, Hessenmöller D, Law BE et al (2008) Old-growth forests as global carbon sinks. Nature 455(7210):213-215

Magurran AE (2004) Measuring Biological Diversity Blackwell Publishing. Malden, MA

Margalef DR (1958) Information theory in ecology, General systems. Real Academica de ciencias y artes de Barcelona 32:373-449
Mensah S, Veldtman R, Du Toit B, Glèlè Kakaï R, Seifert T (2016) Aboveground biomass and carbon in a South African Mistbelt forest and the relationships with tree species diversity and forest structures. Forests 7(4):79. https://doi. org/10.3390/f7040079

Misra R (1968) Ecology Workbook. Oxford and IBH Publ. Co. Calcutta. p 244

Mukherjee PK, Jain AK, Singhal S, Singha NB, Singh S, Kumud K, Seth P, Patel RC (2019) U-Pb zircon ages and Sm-Nd isotopic characteristics of the Lesser and Great Himalayan sequences, Uttarakhand Himalaya, and their regional tectonic implications. Gondwana Res 75:282-297. https://doi.org/10.1016/j. gr.2019.06.001

Nandy SN, Dhyani PP, Samal PK (2006) Resource information database of Indian Himalaya, ENVIS Monograph 3. GB Pant Institute of Himalayan Environment and Development, Kosi-Katarmal, Almora

Negi JDS, Manhas RK, Chauhan PS (2003) Carbon allocation in different components of some tree species of India: a new approach for carbon estimation. Curr Sci 85(11):1528-1531

Newman GS, Arthur MA, Muller RN (2006) Above- and belowground net primary production in a temperate mixed deciduous forest. Ecosystems 9(3):317-329. https://doi.org/10.1007/s10021-006-0015-3

Osuri AM, Madhusudan MD, Kumar VS, Chengappa SK, Kushalappa CG, Sankaran M (2014) Spatio-temporal variation in forest cover and biomass across sacred groves in a human-modified landscape of India's Western Ghats. Biol Conserv 178:193-199

Pala NA, Negi AK, Gokhale Y, Aziem S, Vikrant KK, Todaria NP (2013) Carbon stock estimation for tree species of Sem Mukhem sacred forest in Garhwal Himalaya, India. J For Res 24:457-460. https://doi.org/10.1007/s11676-0130341-1

Pariyar S, Volkova L, Sharma RP, Sunam R, Weston CJ (2019) Aboveground carbon of community-managed Chirpine (Pinus roxburghii Sarg.) forests of Nepal based on stand types and geographic aspects. PeerJ 7:e6494. https://doi. org/10.7717/peerj.6494

Rai ID, Adhikari BS, Rawat GS, Bargali K (2012) Community structure along timberline ecotone in relation to micro-topography and disturbances in Western Himalaya. Not Sci Biol 4(2):41-52. https://doi.org/10.15835/nsb42 7411

Rai ID, Padalia H, Singh G, Adhikari BS, Rawat GS (2020) Vegetation dry matter dynamics along treeline ecotone in Western Himalaya, India. Trop Ecol 61: 116-127. https://doi.org/10.1007/s42965-020-00067-9

Rai ID, Singh G, Rawat GS (2017) Plants of Kedarnath Wildlife Sanctuary, Western Himalaya: A Field Guide. Bishen Singh Mahendra Pal Singh, Dehradun

Rai S, Pandey A, Badola HK (2018) Biomass and carbon stock estimation across the timberline of Khangchendzonga National Park, Eastern Himalaya, India. Taiwania 63(4):311-320. https://doi.org/10.6165/tai.2018.63.311

Rajwar GS (1993) Garhwal Himalaya: ecology and environment. APH Publishing, New Delhi

Rao P, Barik SK, Pandey HN, Tripathi RS (1990) Community composition and tree population structure in a sub-tropical broad-leaved forest along a disturbance gradient. Vegetatio 88(2):151-162

Rawat YS, Singh JS (1988) Structure and function of oak forests in central Himalaya. I. Dry matter dynamics. Ann Bot 62(4):397-411

Sahu SC, Suresh HS, Ravindranath NH (2016) Forest structure, composition and above ground biomass of tree community in tropical dry forests of Eastern Ghats, India. Not Sci Biol 8(1):125-133

Samreth V, Chheng K, Monda Y, Kiyono Y, Toriyama J, Saito S, Saito H, Ito E (2012) Tree biomass carbon stock estimation using permanent sampling plot data in different types of seasonal forests in Cambodia. Jpn Agric Res Q 46(2):187-192. https://doi.org/10.6090/jarq.46.187

Saxena AK, Singh SP, Singh JS (1984) Population structure of forests of Kumaun Himalaya: Implications for management. J Environ Manag 19(4): 307-324

Schroeder P, Brown S, Mo J, Birdsey R, Cieszewski C (1997) Biomass estimation for temperate broadleaf forests of the United States using inventory data. For Sci 43(3):424-434. https://doi.org/10.1093/forestscience/43.3.424

Shahid M, Joshi SP (2015) Biomass and carbon stock assessment in moist deciduous forests of Doon valley, western Himalaya, India. Taiwania 60(2):71-76. https://doi.org/10.6165/tai.2015.60.71

Shannon CE, Weaver W (1949) The mathematical theory of communication. University of Illinois Press, Urbana, IL

Sharma CM, Baduni NP, Gairola S, Ghildiyal SK, Suyal S (2010) Tree diversity and carbon stocks of some major forest types of Garhwal Himalaya, India. For Ecol Manag 260(12):2170-2179. https://doi.org/10.1016/j.foreco.2010.09.014 
Sharma CM, Gairola S, Baduni NP, Ghildiyal SK, Suyal S (2011) Variation in carbon stocks on different slope aspects in seven major forest types of temperate region of Garhwal Himalaya, India. J Biosci 36(4):701-708. https://doi.org/10.1 007/s12038-011-9103-4

Sharma CM, Tiwari OP, Rana YS, Krishan R, Mishra AK (2016) Plant diversity, tree regeneration, biomass production and carbon storage in different oak forests on ridge tops of Garhwal Himalaya. J For Environ Sci 32(4):329-343

Sharma CM, Tiwari OP, Rana YS, Krishan R, Mishra AK (2018) Elevational behaviour on dominance-diversity, regeneration, biomass and carbon storage in ridge forests of Garhwal Himalaya, India. For Ecol Manag 424:105-120. https://doi. org/10.1016/j.foreco.2018.04.038

Singh JS, Singh SP (1987) Forest vegetation of the Himalaya. Bot Rev 53(1):80192. https://doi.org/10.1007/BF02858183

Singh KK, Prakash A (2002) Flora of Rajaji National Park. Bishen Singh Mahendra Pal Singh, Dehradun

Singh P, Thapa RS (1988) Defoliation epidemic of Ascotis selenaria imparata Walk. (Lepidoptera: Geometridae) in sal forest of Asarori Range, West Dehra Dun Division. Indian Forester 114(5):269-274

Singh SP, Adhikari BS, Zobel DB (1994) Biomass, productivity, leaf longevity, and forest structure in the central Himalaya. Ecol Monogr 64(4):401-421. https://doi.org/10.2307/2937143

Singh SP, Sah P, Tyagi V, Jina BS (2005) Species diversity contributes to productivity-Evidence from natural grassland communities of the Himalaya. Curr Sci 89(3):548-552

Singh SP, Singh JS (1986) Structure and function of the Central Himalayan oak forests. Proc Indian Acad Sci (Plant Sci) 96(3):159-189

Sintayehu DW, Belayneh A, Dechassa N (2020) Aboveground carbon stock is related to land cover and woody species diversity in tropical ecosystems of Eastern Ethiopia. Ecol Process 9:37. https://doi.org/10.1186/s13717-020-00237-6

Sist P, Mazzei L, Blanc L, Rutishauser E (2014) Large trees as key elements of carbon storage and dynamics after selective logging in the Eastern Amazon. For Ecol Manag 318:103-109

Slik JWF, Paoli G, McGuire K, Amaral I et al (2013) Large trees drive forest aboveground biomass variation in moist lowland forests across the tropics. Glob Ecol Biogeogr 22(12):1261-1271

Son Y, Noh NJ, Kim RH, Koo JW, Yi MJ (2007) Biomass and nutrients of planted and naturally occurring Pinus koraiensis in Korea. Eurasian J For Res 10(1):41-50

Sundriyal RC, Sharma D (1996) Anthropogenic pressure on tree structure and biomass in the temperate forest of Mamlay watershed in Sikkim. For Ecol Manag 81(1-3):113-134

Szwagrzyk J, Gazda A (2007) Above-ground standing biomass and tree species diversity in natural stands of Central Europe. J Veg Sci 18(4):555-562

Tans PP, Fung IY, Takahashi T (1990) Observational constraints on the global atmospheric $\mathrm{CO}_{2}$ budget. Science 247(4949):1431-1438. https://doi.org/1 $0.1126 /$ science. 247.4949 .1431

Thapa-Magar KB, Shrestha BB (2015) Carbon stock in community managed Hill Sal (Shorea robusta) forests of Central Nepal. J Sustain For 34(5):483-501. https://doi.org/10.1080/10549811.2015.1031251

Thokchom A, Yadava PS (2017) Biomass and carbon stock along an altitudinal gradient in the forest of Manipur, Northeast India. Trop Ecol 58(2):389-396

Tilman D, Lehman CL, Thomson KT (1997) Plant diversity and ecosystem productivity: theoretical considerations. Proc Natl Acad Sci 94(5):1857-1861. https://doi.org/10.1073/pnas.94.5.1857

Tilman D, Reich PB, Knops J, Wedin D, Mielke T, Lehman C (2001) Diversity and productivity in a long-term grassland experiment. Science 294(5543):843-845 https://doi.org/10.1126/science.1060391

Tinker D, Stakes GK, Arcano RM (2010) Allometric equation development, biomass, and aboveground productivity in Ponderosa pine forests, Black Hills, Wyoming Western J Appl For 25(3):112-119. https://doi.org/10.1093/wjaf/25.3.112

Turner J, Singer MJ (1976) Nutrient distribution and cycling in a sub-alpine coniferous forest ecosystem. J Appl Ecol 13(1):295-301

UNFCCC (2015) Measurements for estimation of carbon stocks in afforestation and reforestation project activities under the clean development mechanism: a field manual

Vikrant KK, Chauhan DS (2014) Carbon stock estimation in standing tree of chir pine and Banj oak pure forest in two Van Panchayats forest of Garhwal Himalaya. J Earth Sci Clim Change 5(10):240. https://doi.org/10.4172/2157-61 7.1000240

Waikhom AC, Nath AJ, Yadava PS (2018) Aboveground biomass and carbon stock in the largest sacred grove of Manipur, Northeast India. J For Res 29(2):425-428. https://doi.org/10.1007/s11676-017-0439-y
Walle IV, Van Camp N, Perrin D, Lemeur R, Verheyen K, Van Wesemael B, Laitat E (2005) Growing stock-based assessment of the carbon stock in the Belgian forest biomass. Ann For Sci 62(8):853-864. https://doi.org/10.1051/forest:2 005076

Zhang Y, Chen HY, Taylor AR (2017) Positive species diversity and above-ground biomass relationships are ubiquitous across forest strata despite interference from overstorey trees. Funct Ecol 31(2):419-426. https://doi.org/10.1111/13 65-2435.12699

Zianis D (2008) Predicting mean aboveground forest biomass and its associated variance. For Ecol Manag 256(6):1400-1407. https://doi.org/10.1016/j.foreco.2 008.07.002

Zuur A, leno EN, Smith GM (2007) Analyzing ecological data. Springer. New York. doi:https://doi.org/10.1007/978-0-387-45972-1

\section{Publisher's Note}

Springer Nature remains neutral with regard to jurisdictional claims in published maps and institutional affiliations.

\section{Submit your manuscript to a SpringerOpen ${ }^{\circ}$ journal and benefit from:}

- Convenient online submission

- Rigorous peer review

- Open access: articles freely available online

High visibility within the field

- Retaining the copyright to your article

Submit your next manuscript at $\boldsymbol{\nabla}$ springeropen.com 